University of Miami Law School University of Miami School of Law Institutional Repository

\title{
Beyond the Great Divide: Federalism Concerns in Municipal Insolvency
}

Andrew B. Dawson

University of Miami School of Law, adawson@law.miami.edu

Follow this and additional works at: https://repository.law.miami.edu/fac_articles

Part of the Bankruptcy Law Commons, and the State and Local Government Law Commons

\section{Recommended Citation}

Andrew B. Dawson, Beyond the Great Divide: Federalism Concerns in Municipal Insolvency, 11 Harv. L. \& Pol'y Rev. 31 (2017).

This Article is brought to you for free and open access by the Faculty and Deans at University of Miami School of Law Institutional Repository. It has been accepted for inclusion in Articles by an authorized administrator of University of Miami School of Law Institutional Repository. For more information, please contact library@law.miami.edu. 


\title{
Beyond the Great Divide: Federalism Concerns in Municipal Insolvency
}

\author{
Andrew B. Dawson*
}

\section{INTRODUCTION}

The rehabilitation of a financially distressed business often requires adjusting both its finances and its operations. Through Chapter 11 of the Bankruptcy Code, 'bankruptcy law provides a tool for financial restructuring and an opportunity for operational restructuring. To be sure, bankruptcy law alone is not a cure-all for a business with a broken business model. For many distressed businesses, however, bankruptcy relief offers an opportunity to address both financial and operational problems. ${ }^{2}$ A struggling airline that files for bankruptcy may, for example, seek to renegotiate its debt obligations as well as to restructure its flight network. ${ }^{3}$ A national chain of retail stores might seek to use bankruptcy to renegotiate with bondholders and to close unprofitable stores. ${ }^{4}$ Operational and financial restructuring often go hand-in-hand, as debt renegotiation may involve changes to the debtor's ownership structure and corporate governance. ${ }^{5}$ And bankruptcy law,

* Associate Professor, University of Miami School of Law. My thanks to Charlton Copeland, Pamela Foohey, Patrick Gudridge, Melissa Jacoby, Eric Madiar, Troy McKenzie, Juliet Moringiello, Christopher Odinet, Chrystin Ondersma, Samir Parikh, Stephen Schnably, and William $\mathrm{H}$. Widen for comments and conversations on this and prior drafts. In addition, I owe thanks to the participants at the Southeastern Association of Law Schools 2014 conference, the ABI's Junior Bankruptcy Scholars Workshop at the Brooklyn Law School, and the Saint Thomas University Developing Ideas Workshop conferences.

111 U.S.C. $\$ \S 1101-74$ (2012).

${ }^{2}$ See Adam J. Levitin, Bankrupt Politics and the Politics of Bankruptcy, 97 CorNelL L. REv. 1399, 1445 (2012) ("If a firm's business is the sale of whale oil, corset stays, bustles, flash bulbs, slide rules, floppy disks, cassette tapes, 8-tracks, or books or CDs in a brick-andmortar store, bankruptcy cannot help it beyond providing an orderly way to redeploy its assets and giving it a dignified funeral."). Of course, who should determine whether the business is viable and when that determination should happen are matters of serious, longstanding disputes. See, e.g., Elizabeth Warren \& Jay Lawrence Westbrook, The Success of Chapter 11: A Challenge to the Critics, $107 \mathrm{MICH}$. L. Rev. 603, 604-05 (2009) (noting and challenging the many criticisms of Chapter 11 as an inefficient tool for weeding out non-viable businesses from the reorganization process).

${ }^{3}$ See, e.g., Evan Perez \& Susan Carey, Delta, Northwest See Bankruptcy as Key to Revival, WALl ST. J. (Sep. 15, 2005), http://www.wsj.com/articles/SB1 12671083630940483 (describing the operational changes Delta proposed as part of its bankruptcy restructuring, including efforts to reconfigure its network and fleet organization).

${ }^{4}$ See, e.g., Ezequiel Minaya, American Apparel Emerges from Bankruptcy Proceedings, WALL ST. J. (Feb. 5, 2016), http://www.wsj.com/articles/american-apparel-emerges-frombankruptcy-proceedings-1454714839 (describing part of the reorganization effort as addressing the chain's outsized "store footprint").

${ }^{5}$ See id. (detailing the change in ownership and corporate structure as the debtor retailer swapped old debts for new equity and converted to a Delaware limited liability corporation); see also Rachel Feintzeig, Sbarro Closer to Bankruptcy Exit, Wall St. J. (Oct. 11, 2012), http://www.wsj.com/articles/SB10001424052970203499704576624922724044108 (describing 
at least as applied to business entities, can facilitate this dual restructuring. ${ }^{6}$

Financially distressed municipalities likewise often require both financial and operational restructuring. For example, a municipality may need to renegotiate its bond debt (financial restructuring) and to scale back the services it provides residents (operational restructuring). Municipalities, however, have a different set of tools available to them than would a corporation. A municipality may seek bankruptcy relief under Chapter 9 of the Bankruptcy Code. This route is available only if the state authorizes it-and, at this point, only twenty-seven states have passed bankruptcy authorization laws. ${ }^{7}$ States may also seek to address municipal distress through state financial rescue laws, whether or not they have authorized access to Chapter 9.

In contrast to the way Chapter 11 facilitates both financial and operational restructuring, Chapter 9 of the Bankruptcy Code formally treats financial and operational restructuring as separate and independent exercises. ${ }^{8}$ Federal bankruptcy law governs financial restructuring; state law governs operational restructuring. Thus, renegotiating bond debt falls within the realm of federal bankruptcy law; scaling back on city services falls within the realm of state law. This divide between debt matters (financial restructuring) and governance matters (operational restructuring) is understood to reflect the unique sovereignty issues that arise in municipal insolvency. ${ }^{9}$ While the power to adjust financial obligations is squarely within Congress's power to "enact uniform laws on the subject of bankruptcies," 10 the states retain the power to govern their municipalities."

This debt-governance dichotomy is firmly entrenched in our understanding of municipal bankruptcy federalism, and it is baked into the statutory structure of the municipal bankruptcy laws under Chapter 9 of the Bankruptcy Code. ${ }^{12}$ This dichotomy is also one of the fundamental bases for

the debt-for-equity swap at the heart of the retail pizza chain's reorganization plan, under which first-lien holders received one hundred percent of the equity in the restructured entity).

${ }^{6}$ See Clayton P. Gillette \& David A. Skeel, Jr., Governance Reform and the Judicial Role in Municipal Bankruptcy, 125 YALE L.J. 1150, 1162 (2016) ("Corporate debtors regularly take advantage of the reorganization process to reshape their governance as well as to restructure their debt.").

${ }^{7}$ Pew Charitable Trusts, The State Role in Local Government Financial DisTRESS 12 (July 2013), http://www.pewtrusts.org/ /media/Assets/2013/07/23/Pew_State_Role_ in_Local_Government_Financial_Distress.pdf [https://perma.cc/EN92-EWWV].

${ }^{8}$ While Chapter 9 provides a means to impose a "plan of adjustment" on non-consenting creditors, it specifically reserves for states the power to control the bankruptcy municipality's political and governmental functions. 11 U.S.C. $\$ \S 903,904$ (2012) (discussed in more detail infra Part I).

${ }^{9}$ See Gillette \& Skeel, supra note 6, at 1166 (noting that the bankruptcy laws "suggest congressional concern with constitutional limitations on federal diminution of state sovereignty in Chapter 9 proceedings").

${ }^{10}$ U.S. Const., art. I, $\$ 8$, cl. 4 ("The Congress shall have Power to . . establish . . . uniform Laws on the subject of Bankruptcies throughout the United States . ....").

"See Gillette \& Skeel, supra note 6, at 1166 (noting that this is the dominant descriptive account of municipal bankruptcy, but challenging the assumption that the Constitution requires such a structure and arguing that this divide is inefficient).

${ }^{12} 11$ U.S.C. $\$ \$ 901-46$ (2012). See discussion of statutory structure infra Part I.C. 
much of the criticism of the municipal bankruptcy laws, both in legal academia and in policy circles. Under this model of debt and governance, Chapter 9 only addresses a city's financial problems without addressing the causes of those problems. ${ }^{13}$ While financial distress may result from exogenous shocks, it frequently results from poor governance. Local government officials may face political and/or structural obstacles to address financial distress, such as raising taxes or scaling back services. Chapter 9 is an ineffective tool, it has been argued, because it fails to address these root causes. ${ }^{14}$

These criticisms have appeared in policy circles as well, most recently in the opposition to any form of bankruptcy relief for Atlantic City, New Jersey, ${ }^{15}$ and for Puerto Rico. ${ }^{16}$

Unfortunately, though, this debt-governance divide is frequently applied in a highly formalistic way that fails as both a descriptive and prescriptive model of municipal bankruptcy federalism. ${ }^{17}$ Such a model, referred to here as the Great Divide Model, assumes that debt and governance are completely separate matters. The role of a court in determining the limits of federal bankruptcy power in this context is simply to determine whether the matter in question is one of debt or governance. Debt matters fall in the federal sphere of power, governance in that of the states. The Great Divide Model rests on two basic assumptions of municipal bankruptcy federalism:

${ }^{13}$ See, e.g., Levitin, supra note 2 , at 1438 (noting the recidivism problem as a consequence of municipal bankruptcy law's non-interference with operational reorganization); Clayton P. Gillette, Fiscal Federalism, Political Will, and Strategic Use of Municipal Bankruptcy, 79 U. CHI. L. Rev. 281, 320 (2012) [hereinafter Gillette, Fiscal Federalism] ("Since $\$ 904$ of the Bankruptcy Code allows local officials to maintain control of taxing and spending decisions during bankruptcy, officials may believe that bankruptcy insulates them from the imposition of obligations that they find politically, if not financially, imprudent."); Omer Kimhi, Chapter 9 of the Bankruptcy Code: A Solution in Search of a Problem, 27 YALE J. on Reg. 351,359 (2010).

${ }^{14}$ Gillette, Fiscal Federalism, supra note 13, at 320. Gillette's concern is actually more acute, as he argues Chapter 9 may further insulate officials from these difficult decisions.

is See, e.g., Stephen M. Sweeney, Taking Over Atlantic City's Finances is Better than Bankruptcy, NJ.com (Jan. 17, 2016), http://www.nj.com/opinion/index.ssf/2016/01/sweeney taking_over_atlantic_citys_finances_is_bet.html [https://perma.cc/B9CM-SS93] (comments of Stephen M. Sweeny, President of the New Jersey Senate, regarding financial options for Atlantic City: "Reorganization of the city's finances under a state takeover would enable the city's various stakeholders, including city officials, community groups, churches, and county and state leaders, to work together to turn around the city - which would not be possible under the supervision of a federal bankruptcy judge.").

${ }_{16}$ See, e.g., Kasia Klimasinka, House Works on Puerto Plan That Faces Skepticism in Senate, Bloomberg (Jan. 26, 2016), http://www.bloomberg.com/politics/articles/2016-01-25/ house-works-on-puerto-rico-plan-that-faces-skepticism-in-senate [https://perma.cc/279HTXPC] (quoting Senator Chuck Grassley of lowa: "The feeling is if we just did a straight Chapter 9, we'd be right back here in five or six years doing it again.").

17 "Formalism" here is used as describing the courts' rule-driven approach to addressing whether a particular power belongs in the federal or state regulatory sphere, not in its meaning in separation of powers law. While "formalism" is a defined term of art in separation of powers law, in which powers are explicitly allocated among the three branches of government and the role of courts is to classify the power exercised is being exercised by the appropriate branch in the appropriate way, see M. Elizabeth Magill, Beyond Powers and Branches in Separation of Powers Law, 150 U. PA. L. Rev. 603, 608 (2001), this article will not address separation of powers issues. 
(1) that Congress has the exclusive power to pass bankruptcy laws; and (2) that there is a clean divide between debt and governance.

This article argues that it is necessary to move away from this model of federalism and toward a more functional approach-an approach that recognizes the purpose of federal municipal bankruptcy laws as a means to address municipal insolvency when state law alone proves inadequate. Without a functional understanding of municipal insolvency federalism, federal bankruptcy law may intrude upon state sovereignty in this context, both when states have authorized the use of federal bankruptcy laws and when they have not.

The recent municipal insolvency crisis has highlighted the need for moving beyond the Great Divide Model. As more municipalities are sinking into financial distress, weighed down in large part by unsustainable legacy costs, ${ }^{18}$ there have been an unprecedented number of municipal bankruptcy filings. ${ }^{19}$ At the same time, states have increasingly sought to address municipal debt problems without bankruptcy relief. ${ }^{20}$ The concomitant increase in both municipal bankruptcy filings and state rescue laws creates more occasions for conflict and uncertainty about the interaction of federal and state law in this field. The Great Divide Model provides little guidance in how such conflicts should be addressed-if matters can be characterized as financial, they fall within the sphere of the bankruptcy laws; if operational, they fall within that of state laws. Since many matters have elements of each, this test is of little help.

When states have authorized municipalities to seek bankruptcy relief, the Great Divide Model has failed to provide a workable framework for analyzing the limits of federal power as applied to matters that fall within the overlapping region between debt and governance. The most prominent issue

${ }^{18}$ See, e.g., Pew Charitable Trusts, A Widening Gap in Cities: Shortfalls in Fund. ing for Pensions and Retiree Health Care 2 (Jan. 2013) (reporting that the largest sixtyone cities in the United States had pension shortfalls of ninety-nine billion dollars in fiscal year 2009, a number which increased fifteen percent among the forty reporting cities in 2010), http://www.pewtrusts.org/ /media/legacy/uploadedfiles/pcs_assets/2013/pewcitypensionsreportpdf.pdf [https://perma.cc/SR3N-9FRB]; Matthew J. Belvedere, If Detroit Cuts Pensions, Will Your City be Next?, CNBC (July 29, 2013), http://www.cnbc.com/id/100920940 [https:// perma.cc/HDQ7-N4DA]; Charles Krauthammer, If Detroit Bankruptcy Succeeds, Other Cities Will Follow, MYSA (July 26, 2013), http://www.mysanantonio.com/opinion/commentary/article/If-Detroit-bankruptcy-succeeds-other-cities-will-4689541.php [https://perma.cc/CX2SZ37F]; Monica Davey et al., Detroit Ruling on Bankruptcy Lifts Pension Protections, N.Y. Times (Dec. 3, 2013), http://www.nytimes.com/2013/12/04/us/detroit-bankruptcy-ruling.html [https://perma.cc/V99P-UYUX] (noting that the outcome in Detroit "is likely to resonate in Chicago, Los Angeles, Philadelphia and many other American cities where the rising cost of pensions has been crowding out spending for public schools, police departments and other services.").

${ }^{19}$ See Gillette \& Skeel, supra note 6, at 1183 (noting that until recently there had been few municipal bankruptcy cases); see also Michelle Wilde Anderson, The New Minimal Cities, 123 YALE L.J. 1118, 1130 (2014) (counting twenty-eight urban municipalities that either sought bankruptcy protection or entered a state receivership program between 2007-2013).

${ }^{20}$ See, e.g., Anderson, supra note 19; Pew Charitable Trusts, supra note 7; Clayton P. Gillette, Dictatorships for Democracy: Takeovers of Financially Failed Cities, 114 CoLum. L. REv. 1373, 1377 (2014). 
that falls in this gray area is that of municipal pension obligations. These obligations are partially financial in character and partially operational, as they are a core platform of the city's relationship with its employees. Can a municipality use bankruptcy law to adjust pension obligations, or are such obligations within the state's power to control municipal governance?

Taking a formalist approach, the Great Divide Model categorizes pension obligations as falling within either the sphere of financial restructuring or operational restructuring. This model ultimately obscures the legal analysis courts have actually used in handling matters such as pensions that fall in this gray area where debt and governance overlap. ${ }^{21}$ For example, as illustrated infra in Detroit's bankruptcy, despite using formalist language, the court's analysis actually reflects a more nuanced balancing of federal and state interests in the treatment of employee and retiree claims. ${ }^{22}$ And by obscuring this legal analysis, the Great Divide Model fails to provide an analytical framework to consider the limits of the municipal bankruptcy laws more broadly. Scholars have long understood that the municipal bankruptcy laws provide indirect means for courts to interfere with local governance even though courts cannot directly mandate operational reforms. ${ }^{23}$ That is, because the line between debt and governance is an artificial one, courts could conceivably demand governance reform under the guise of debt reform. For example, can a court use its power to deny plan confirmation as a "stick" to force the debtor to undergo operational changes? Recent bankruptcy cases illustrate that this indirect control may be occurring to an even greater extent than previously contemplated. ${ }^{24}$ The Great Divide Model's formalist division between debt and governance opens the door for such indirect federal control, without taking into consideration broader principles of municipal bankruptcy federalism.

When states have sought to address municipal insolvency without resorting to federal bankruptcy relief, the Great Divide Model of municipal bankruptcy has also threatened to disrupt state control over distressed municipalities. Some state financial rescue laws have been invalidated for conflicting with the Bankruptcy Clause and with Chapter 9 of the Bankruptcy Code, as they arguably intrude upon Congress's exclusive right to pass bankruptcy laws. This approach was first articulated in dicta in a Sixth Circuit per

${ }^{21}$ See Frederick Schauer, Formalism, 97 YALE L.J. 509, 513-14 (1988) (describing “one view of the vice of formalism" is that it may "disguise a choice in the language of definitional inexorability," and thus "obscures that choice and thus obstructs questions of how it was made and whether it could have been made differently").

${ }^{22}$ See infra Part II.B.

${ }^{23}$ See Michael W. McConnell \& Randal C. Picker, When Cities Go Broke: A Conceptual Introduction to Municipal Bankruptcy, 60 U. CH. L. Rev. 425, 474 (1993) (describing the potential for "judicial control by a wink and a nod" by refusing to confirm a city's debt adjustment plan).

${ }^{24}$ See Melissa B. Jacoby, Federalism Form and Function in the Detroit Bankruptcy, 33 Yale J. ON Reg. 55 (2016) (outlining the "Detroit Blueprint," whereby the court was able to use a variety of means-from case management, mediation, and other procedural devicesthat can expand the judicial role in municipal bankruptcy cases). 
curiam opinion. ${ }^{25}$ The Supreme Court, however, gave it a significant boost in its recent opinion on Puerto Rico's efforts to restructure its debts outside of bankruptcy law. ${ }^{26}$ In that case, the Court held that Chapter 9 of the Bankruptcy Code preempts Puerto Rico's Recovery Act even though Puerto Rican municipalities are ineligible for bankruptcy relief, reasoning that Chapter 9 preempts all state municipal bankruptcy laws, even as to states that have not opted into the municipal bankruptcy laws. ${ }^{27}$

In arguing for this shift toward a functional approach, this article is not the first to criticize the Great Divide Model's formalism. To be sure, academics have long poked holes in this model, noting that the statutory "wall" between debt and governance is actually quite permeable in practice. ${ }^{28}$ Bankruptcy courts can influence governance matters through the confirmation requirements, as Michael McConnell and Randal Picker first noted a quartercentury ago ${ }^{29}$ Melissa Jacoby's work on Detroit's bankruptcy has illustrated how courts can influence governance matters more subtly, and perhaps more pervasively, through case management strategies designed to encourage settlements. ${ }^{30}$

Scholars have also taken some preliminary steps toward a theoretical justification for this permeability. Juliet Moringiello has argued for a cooperative model of municipal bankruptcy in which the municipal bankruptcy laws are intended to be supplemented by state law participation. ${ }^{31}$ Clayton Gillette and David Skeel have argued that the Constitution itself does not mandate a strict debt-governance distinction in federal bankruptcy law and that bankruptcy law might be improved by giving courts a greater role in operational restructuring. ${ }^{32}$ And Samir Parikh has argued that the Contracts Clause leaves more debt-adjustment power to the states than is generally recognized, thus challenging the assumption that federal law provides the exclusive means for debt adjustment. ${ }^{33}$

Nonetheless, the debt-governance dichotomy still forms the foundation of much academic literature on this subject and underlies most critiques of curiam).

${ }^{25}$ Pontiac Retired Emps.' Ass'n v. Schimmel, 751 F.3d 427, 430-31 (6th Cir. 2014) (per

${ }^{26}$ Puerto Rico v. Franklin Cal. Tax-Free Tr., 136 S. Ct. 1939, 1947 (2016).

${ }^{27} \mathrm{Id}$.

${ }^{28}$ See, e.g., McConnell \& Picker, supra note 23, at 474 (arguing that courts could use the best interests test to indirectly force operational changes).

${ }^{29}$ Id.

${ }^{30}$ Jacoby, supra note 24.

${ }^{31}$ Juliet M. Moringiello, Goals and Governance in Municipal Bankruptcy, 71 WASH. \& LeE L. REv. 403, 480-81 (2014) (arguing that the municipal bankruptcy laws were deliberately structured in order to invite state law participation in the bankruptcy proceedings).

${ }^{32}$ Gillette \& Skeel, supra note 6, at 1153.

${ }^{33}$ Samir Parikh, A New Fulcrum Point for City Survival, 57 WM. \& MARY L. Rev. 221 (2015) (arguing that states are best positioned to rehabilitate distressed municipalities, but recognizing that municipal bankruptcy law-even if never invoked-is a key component of any municipal rehabilitation effort); id. at 262 ("I argue that the Contracts Clause, as it appears in the Constitution and various state constitutions, has been widely misunderstood. In fact, by utilizing carefully tailored, temporary contractual modifications, distressed municipalities have far more leverage and bargaining power than they likely suspect."). 
Chapter 9. ${ }^{34}$ McConnell and Picker concluded that Chapter 9 "serves little use: it does little to address city problems and ... even impedes the ability of states to institute superior schemes for dealing with cities that have gone broke." 35 Omer Kimhi has argued that distressed municipalities "need . . . a more pervasive and in-depth recovery process-a process that the Bankruptcy Code, at least in its current form, does not contain." 36 Gillette has argued that the debt-governance divide, i.e., the inability of bankruptcy courts "to impose resource adjustments," is the source of cities' ability to engage in strategic use of bankruptcy. ${ }^{37}$ And Adam Levitin has argued that the lack of authority to order operational restructuring may lead to recidivism problems, as municipalities may end up emerging from bankruptcy just as unhealthy as they entered. ${ }^{38}$

This article proposes a decisive break with Great Divide Model as a foundation for understanding municipal bankruptcy law. Instead of presuming the existence of two separate spheres of federal and state power, it proposes a thoroughly functional approach that fully recognizes the significant overlap between debt and governance and finds room for regulatory overlap to accommodate it. It proposes an approach in which both federal and state law work together through the bankruptcy process while still respecting federal supremacy. Such an approach is consistent with the history and structure of the municipal bankruptcy laws, which have been fashioned with an eye to provide limited federal relief to states without interfering with governmental functions. This approach also helps to frame municipal bankruptcy federalism questions in a way that more directly and transparently addresses the state sovereignty concerns that arise in this context. Namely, it creates a framework for analyzing the limits of the federal bankruptcy power, and it ensures a space for state law to coexist with federal bankruptcy law.

Accordingly, Part I begins with a description of municipal bankruptcy law, highlighting the dual and, at times, overlapping roles of federal and state law that distinguish municipal bankruptcy federalism from general bankruptcy federalism. Although the municipal bankruptcy laws under Chapter 9 of the Bankruptcy Code are very similar to the corporate reorganization laws under Chapter 11, Chapter 9 reflects sovereignty concerns that are unique to municipal bankruptcy. ${ }^{39}$ These concerns are reflected throughout Chapter 9, from how a municipal bankruptcy case may be commenced to how it may be concluded through a debt adjustment plan. ${ }^{40}$ These provisions illustrate that the divide between debt and governance is quite porous in areas, presenting opportunities for "leaks" between the debt-governance

${ }^{34}$ See, e.g., Levitin, supra note 2 , at 1438 (noting the recidivism problem as a consequence of municipal bankruptcy law's non-interference with operational reorganization); Gillette, supra note 13; Kimhi, supra note 13, at 359.

${ }^{35}$ McConnell \& Picker, supra note 23, at 494.

${ }^{36}$ Kimhi, supra note 13 , at 385 .

${ }^{37}$ Gillette, Fiscal Federalism, supra note 13, at 325.

${ }^{38}$ Levitin, supra note 2, at 1438.

${ }^{39}$ See infra Part I.

${ }^{40}$ See infra Part I. 
divide: federal courts may indirectly require operational changes to bankrupt municipalities, and state law may indirectly shape distributional priorities.

Part II describes the dominant Great Divide Model of municipal bankruptcy federalism. Debt and governance are treated as independent separate spheres, with federal law exercising a monopoly power over debt adjustment and state law over operational adjustments. This approach has been apparent both in bankruptcy cases and in challenges to state financial rescue laws. This part of the article concludes with two bankruptcy case studies and two case studies of challenges to non-bankruptcy restructuring attempts, including the Court's recent ruling regarding Puerto Rico's public debt restructuring law. ${ }^{41}$

Part III identifies and challenges the two key assumptions underlying the Great Divide Model: namely, that Congress has the exclusive power to pass bankruptcy laws and that there exists a clean divide between debt and governance. Although these general principles can provide a useful heuristic for characterizing the municipal bankruptcy laws, neither is entirely accurate. As argued in this part, the Court has never found that the constitutional power to pass "uniform Laws on the subject of Bankruptcies" gave Congress the exclusive power to pass bankruptcy laws. ${ }^{42}$ The uniformity requirement does much less work than that, resulting in a bankruptcy system that is decidedly non-uniform in some important ways-in particular, as applied to insolvent municipalities. ${ }^{43}$ In addition, debt and governance matters frequently overlap, placing stress on this formal categorical distinction. The existence of these overlapping regions requires an analysis of the limits of Congress's power in the field of municipal insolvency - an analysis that is obscured by the Great Divide Model.

Part IV presents a more functional approach to analyzing these municipal bankruptcy federalism questions. This approach recognizes that Congress and the states share responsibility for insolvency regulation, albeit subject to federal preemption. It also recognizes that federal adjustment of debts will likely intrude upon matters of governance and vice versa. This approach is consistent with the history and development of the municipal bankruptcy laws, and it better captures the way courts have sought to balance federal and state interests in municipal bankruptcy cases. This functional approach further provides a more useful framework in considering the limits of federal intrusion into municipal governance.

Part IV also discusses the role this functional approach can take in connecting municipal bankruptcy federalism with broader conversations of "our federalism(s)." $" 44$ The Great Divide Model's formalist approach reflects the "dual federalism" model that dominated Tenth Amendment analysis in the

${ }^{41}$ Puerto Rico v. Franklin Cal. Tax-Free Tr., 136 S. Ct. 1939 (2016).

${ }^{42}$ See infra Part III.

${ }^{43}$ See Lawrence Ponoroff, Constitutional Limitations on State-Enacted Bankruptcy Exemption Legislation and the Long Overdue Case for Uniformity, 88 Am. BankR. L.J. 353 (2014).

${ }^{44}$ Heather K. Gerken, Our Federalism(s), 53 WM. \& MARY L. Rev. 1549 (2012). 
beginning of the twentieth century-the time period when the first municipal bankruptcy laws were first drafted and interpreted by the Court. In that way, municipal bankruptcy federalism is out of sync with modern federalism theories and jurisprudence. Drawing from some modern federalism theories may shed light on the limits of federal interference into the governance of insolvent municipalities.

\section{Municipal Bankruptcy Background}

This part explains how municipal bankruptcy law raises important issues of federal-state relations. While these issues share some characteristics with general bankruptcy federalism, this part highlights how the issues in municipal insolvency are unique in important respects. The municipal bankruptcy laws in Chapter 9 of the Bankruptcy Code mirror those of corporate reorganization laws in Chapter 11 to a large extent, but Chapter 9 has unique provisions that aim to limit federal intrusion into municipal governance. For example, municipalities may not file bankruptcy unless authorized to do so by their state, and once in bankruptcy, the bankruptcy laws leave intact the state's ability to control the municipality's governmental functions. ${ }^{45}$ As analyzed in this part, these provisions reflect the municipal bankruptcy laws as a mechanism to facilitate federal and state cooperation in the resolution of municipal insolvency. Unlike questions of preemption, where either federal or state law will apply, this municipal bankruptcy federalism is not necessarily a zero-sum game-there is room for both federal and state control.

This part begins with a historical description of the municipal bankruptcy laws, which illustrates an enduring tension between efforts to craft a federal solution to municipal insolvency crises and concerns about the states' role in controlling their own municipalities. It then explores the statutory framework that has developed since, illustrating these competing concerns for a uniform law for restructuring municipalities' debt obligations that also leaves states in control over operational matters.

\section{A. Brief History of the Origins of Municipal Bankruptcy Law}

The federalism concerns underlying the Great Divide Model are longstanding. They are apparent in the debates leading up to the first municipal bankruptcy laws, in the text of those first laws, and in the early Supreme Court decisions examining the constitutionality of those laws. They influenced later amendments to the municipal bankruptcy laws, and they continue to inform present-day attitudes toward the roles of the federal and state governments to address municipal insolvency. ${ }^{46}$

4511 U.S.C. $\$ \$ 109(\mathrm{c}), 903,904$ (2012).

${ }^{46}$ See Ashton v. Cameron Cty. Water Improvement Dist., 298 U.S. 513, 533 (1936) (Cardozo, J., dissenting) ("Often the holders of the bonds, to the extent of 90 per cent. [sic] or more were ready to scale down the obligations and put the debtor on its feet. A recalcitrant 
Congress passed the first municipal bankruptcy laws in the depths of the Great Depression. ${ }^{47}$ During that time, many municipalities were struggling to pay their bond obligations, and the states were largely incapable of providing relief..$^{48}$ Without a federal bankruptcy option, states faced the difficult problem of addressing municipal insolvency within the constraints of the Contracts Clause..$^{99}$ That clause prohibits states from passing laws that would impair the obligation of contracts, and bond debts are contractual in nature..$^{50}$ This prohibition would bar state laws purporting to discharge already existing debts, and it might invalidate state laws that would alter the terms of the debtor obligation, either by reducing the amount of the indebtedness (a "debt composition") or by extending the maturity date (an "extension"). ${ }^{51}$ Whether such an alteration would give rise to a constitutional "impairment" was uncertain (and remains so), meaning that any such attempt was likely to be mired in bondholder litigation..$^{52}$

Against this backdrop, Congress enacted the first municipal bankruptcy law in $1934 . .^{53}$ It provided a way for municipalities to propose a plan to adjust their debts and impose the adjustment on all creditors. ${ }^{54}$ The legisla-

minority had capacity to block the plan. Nor was there hope for relief from statutes to be enacted by the states. The Constitution prohibits the states from passing any law that will impair the obligation of existing contracts, and a state insolvency act is of no avail as to obligations of the debtor incurred before its passage. Relief must come from Congress if it is to come from any one."); Is Chapter 9 Bankruptcy the Ultimate Remedy for Financially Distressed Municipalities: Are there Better Resolution Mechanisms?: Hearing on H.B. 298, 2015-16 99th Gen. Assemb. 3 (IIl. 2015) (statement of James E. Spiotto) ("The municipal debt adjustment provisions of the Bankruptcy Act enacted in 1934 thus reflected an attempt to protect municipalities from debilitating disputes with creditors."), https://www.civicfed.org/ sites/default/files/James\%20Spiotto\%20Testimony\%20-\%20Subject\%20Matter\%20Hearing\% 20on\%20HB298.pdf [https://perma.cc/Z6BF-LPJC ].

${ }^{47}$ Pub. L. No. 251, 48 Stat. 798 (1934).

${ }^{48}$ See Ashton, 298 U.S. at 534 (Cardozo, J., dissenting).

${ }^{49}$ See id.

${ }^{50}$ U.S. Const., art. I, $\S 10$, cl. 1 ("No State shall . . pass any . . Law impairing the Obligation of Contracts .....").

${ }^{51}$ See Sturges v. Crowninshield, 17 U.S. 122, 194 (1819); Ogden v. Saunders, 25 U.S. 213, 368-69 (1827) (discussing margins of the Contracts Clause); Ropico, Inc. v. City of New York, 425 F. Supp. 970, 982 (S.D.N.Y. 1976) (analyzing the distinction between "compositions" and "extensions") (discussed infra notes 172-80 and accompanying text); see also Parikh, supra note 33, at 265 (discussing the evolution of the Contracts Clause jurisprudence).

${ }^{52}$ Bills to Amend an Act Entitled "An Act to Establish a Uniform System of Bankruptcy Throughout the United States", Approved July 1, 1898, and Acts Amendatory Thereof and Supplementary Thereto: Hearings on S. 1868 and H.R. 5950 Before a S. Subcomm. on the Judiciary, 73rd Cong. 13 (1933) [hereinafter Bills to Amend] (statement of Hon. J. Mark Wilcox) (characterizing this bondholder litigation as resulting in "endless litigation, resulting in expense both to the taxpayer and to the bondholder, with the result that nothing has been accomplished for any of them"); see also Spiotto, supra note 46.

${ }_{53}$ Pub. L. No. 251, 48 Stat. 798 (1934).

${ }^{54} \mathrm{Id}$. at $\$ 80$ (a) (authorizing a municipality to file a petition for relief provided it had a plan of readjustment that had been preapproved by holders of thirty percent of indebtedness for "drainage, irrigation, reclamation, and levee districts and 51 per centum in the case of all other taxing districts"); $\S 80$ (d) (permitting the court to confirm the plan of readjustment if approved by "66 $2 / 3$ per centum in the case of drainage, irrigation, reclamation, and levee districts and creditors holding 75 per centum in the case of all other taxing districts"); $\S 80(\mathrm{e})$ (authorizing court to confirm a plan that satisfies the statutory requirements). 
tive history leading up to this first municipal bankruptcy law reflects three concerns about the legitimacy of the new law: the first dealing with Congress's power to pass the law under the Bankruptcy Clause, and the second and third arising from concerns about state sovereignty. ${ }^{55}$ The first concern was largely put aside, as it was generally agreed that the municipal bankruptcy law would result in a debt composition, which the Court had long recognized as within the bankruptcy power. ${ }^{56}$ The two sovereignty concerns were more contested.

The first sovereignty concern was whether the mere act of filing bankruptcy would interfere with a state's control of its municipality. ${ }^{57}$ The general consensus in the legislative history was that a state must consent to a municipal bankruptcy filing. ${ }^{58}$ The main disagreement on this front was whether consent must be explicit or whether it could be implicit, based, for example, on a state's decision to allow the municipality to issue bonds. ${ }^{59}$ The issue of state consent has persisted throughout the development of municipal bankruptcy laws. ${ }^{60}$

The second sovereignty concern related to the bankruptcy law's potential interference with a state's governmental power. ${ }^{61}$ Despite state sovereignty concerns, the legislative history behind the act reflected an understanding that the bill would pass constitutional muster since the law focused singularly on financial restructuring. ${ }^{22}$ Drawing largely from the era's intergovernmental tax immunity doctrine, which dealt with the limits of the federal government's ability to tax municipalities, ${ }^{63}$ the legislative history recognized the dual character of municipalities as both private and public

${ }^{55}$ See Bills to Amend, supra note 52.

${ }^{56} \mathrm{Id}$. at 52 . There were some reservations about the scope of the Bankruptcy Clause, but they do not appear to have been widely shared. According to testimony of Mr. Woods, the consensus opinion of municipal and bankruptcy laws was that the law was squarely within the bankruptcy power. See id.

${ }^{57}$ Id.

${ }^{58}$ Adjustment of Indebtedness of Municipal Corporations: Hearing on H.R. 1670, H.R. 3083, H.R., 4311, and H.R. 5267 Before the H. Comm. on the Judiciary, 73rd Cong. 1 (1933).

${ }^{59}$ Compare id. at 178 (memorandum from the Department of Justice) ("Congress cannot regulate directly or indirectly, the fiscal policies of the States or their governmental agencies. The States are entitled to determine for themselves whether or not their municipalities shall be permitted to go into Federal bankruptcy court and adjust their debts. For Congress to assume to grant this authority when it has not been given by the State itself, either by general law or by special enactment, would seem to constitute a prohibited encroachment into a domain where, under our Constitution, the State is supreme.") with Bills to Amend, supra note 52 (statement of David M. Woods) ("I grant that the Congress cannot give them the power, but the States have already granted that power, either expressly or by implication.").

${ }^{60}$ See Daniel J. Freyberg, Municipal Bankruptcy and Express State Authorization to Be A Chapter 9 Debtor: Current State Approaches to Municipal Insolvency-and What Will States Do Now?, 23 Ohio N.U. L. Rev. 1001 (1997).

${ }^{6}$ See Mem. from Homer S. Cummings, Att'y Gen. of the United States, to Hatton W. Sumners, Chair, H. Judiciary Comm. (Apr. 21, 1933), in To Amend the Bankruptcy Act Municipal and Private Corporations: Hearing on H.R. J670, H.R. 3083, H.R. 4311, H.R. 5009 and H.R. 5267 Before the H. Comm. on the Judiciary, 73d Cong. 176 (1933).

${ }^{62} I d$. at 180 .

${ }^{63}$ Id. at 177-78. As discussed infra note 287 , the intergovernmental tax doctrine from the Great Depression era has since been rejected as unworkable. 
entities ${ }^{64}$ Municipalities are public in nature to the extent that they exercise governmental powers; they are private corporations in nature when they engage in private business. ${ }^{65}$ So long as municipal bankruptcy law applied only to municipalities in their private capacity, it was anticipated that the law would be constitutional. ${ }^{66}$ The only question was whether this "dual character" would apply only to municipal corporations-such as water or sewer districts-or also to cities and counties, whose governmental character might be so dominant as to outweigh its private character. ${ }^{67}$

These sovereignty concerns_-state control over the filing of bankruptcy and state control over governmental functions-would underlie the development of the municipal bankruptcy laws as they developed through the courts and in later amendments. That is, from the very beginning, Congress has recognized that municipalities and municipal corporations serve both private and public functions, and it has expressed concern that bankruptcy law be limited to only private functions. The attempts to strictly separate these functions provide the foundation for the Great Divide Model.

\section{B. Sovereignty Concerns in Ashton and Bekins}

The cases of Ashton v. Cameron County Water Improvement District and United States v. Bekins discussed in this section set forth the basic architecture of the municipal bankruptcy laws that highlights two key attributes for balancing federal and state power: (1) the state has to consent to the use of municipal bankruptcy law, and (2) federal interference should be minimal.

In Ashton, the Supreme Court found that the first municipal bankruptcy law unconstitutionally infringed on states' rights to control their own fiscal affairs. ${ }^{68}$ The states have the right to control their own municipalities, which includes the power to manage their own affairs through contractual relationships with other parties. Bankruptcy, with its "especial purpose . . . to interfere with the relations between the parties concerned," would necessarily interfere with that internal control, according to the majority. ${ }^{69}$ Although the Court recognized that such a holding would render states helpless to address the problem of municipal insolvency, it held that to allow states to obtain

${ }^{64}$ See David M. Woods, Constitutionality of the Sumners Municipal Relief Bill, H.R. 5950, 10 Am. Bankr. Rev. Monthly Mag. Law. Bankers \& Bus. Men 175, 179 (1933) (quoting Indian Motorcycle Co. v. United States, 283 U.S. 570, 576 (1931) for the language "the [interstate tax] immunity does not extend to anything lying outside or beyond governmental functions and their exertion").

${ }^{65}$ See Vilas v. City of Manila, 220 U.S. 345, 356 (1911) (citing South Carolina v. United States, 199 U.S. 437, 461 (1905); Lloyd v. New York, 5 N.Y. 369, 374 (1851); W. Sav. Fund. Soc. v. Philadelphia, $31 \mathrm{~Pa} .175,183(1851)$ ).

${ }^{66}$ See id.

${ }^{67}$ See Bills to Amend, supra note 52, at 47-49 (statement of David M. Wood); see also Woods, supra note 64.

${ }^{68}$ See Ashton v. Cameron Cty. Water Improvement Dist., 298 U.S. 513, 531 (1936).

${ }^{69} \mathrm{Id}$. at $530-31$. 
such federal relief would unconstitutionally expand the powers of Congress to interfere with the "obligations of states or their political subdivisions."

Congress quickly passed an amended municipal bankruptcy law in 1937 with only minor changes. ${ }^{71}$ The law went before the Supreme Court again and was upheld in United States v. Bekins. ${ }^{72}$ The Court made no effort to highlight the qualities of the revised act that saved this version from the fate of the 1934 Act, and commentators have acknowledged that the two laws were substantially similar. ${ }^{73}$ The main difference, perhaps, is that $B e$ kins arose after the notorious "switch in time" that saved the Court from Roosevelt's proposed Court-packing plan. ${ }^{74}$ The Bekins Court again recognized the potential constitutional problem that might arise if the federal bankruptcy law could intrude into local municipal governance. However, the Court highlighted three aspects of the municipal bankruptcy laws that avoided this problem: (1) the bankruptcy power can be exercised only with state consent, (2) "[n]o interference with the fiscal or governmental affairs of a political subdivision is permitted," and (3) "no control or jurisdiction over that property and those revenues of the petitioning agency necessary for essential governmental purposes is conferred by the bill." 75 Under that scheme, the Court held that

[W]e have co-operation to provide a remedy for a serious condition in which the States alone were unable to afford relief .... The bankruptcy power is competent to give relief to debtors in such a plight and, if there is any obstacle to its exercise in the case of the districts organized under state law it lies in the right of the State to oppose federal interference. The State steps in to remove that obstacle. The State acts in aid, and not in derogation, of its sovereign powers. ${ }^{76}$

${ }^{70} \mathrm{Id}$.

${ }^{71}$ McConnell \& Picker, supra note 23, at 452 (noting that "[w]hile not expressly overru]ing Ashton, the Court upheld the new Act without identifying any specific points of distinction from the earlier Act"). The two acts were not identical, as Robert H. Jackson, then serving as Solicitor General, outlined in the United States's brief in Bekins. See Br. for the United States at 79-82, United States v. Bekins, 304 U.S. 27 (1938) (No. 757) (listing the following differences: (1) the old Act permitted the court to order the debtor to file schedules and provide information to creditors; and (2) the old Act called for a "debt readjustment," which might be interpreted as more sweeping than the revised act's "debt composition").

${ }_{72}$ See United States v. Bekins, 304 U.S. 27, 27 (1938).

${ }^{73}$ Kenneth Klee, Bankruptcy and the Supreme Court 152 (LexisNexis 2008) ("A comparison of Chapters IX and X, however, leads one to wonder what statutory differences were constitutionally significant. Perhaps there were none.").

${ }^{74}$ Commentators have largely agreed that the outcome in Bekins is better understood to reflect the "switch-in-time"--that is, the Supreme Court's jurisprudential shift following President Roosevelt's proposal to increase the size of the Supreme Court-rather than substantive differences in the two acts. See Gillette \& Skeel, supra note 6, at $1176 \mathrm{n} .108$ (gathering sources supporting this hypothesis).

${ }^{75}$ Bekins, 304 U.S. at 51.

${ }^{76}$ Id. at 53-54. 
Thus, Bekins recognized states' sovereign control over their own municipalities and found that granting states a municipal bankruptcy option supported the exercise of that control. Federal law gave the states a tool to adjust current indebtedness that was otherwise unavailable under the Contracts Clause.

Congress's enduring concern with state-sovereignty is evident in several amendments to municipal bankruptcy law, discussed in Section C. Section D will introduce a third main attribute of municipal bankruptcy laws: uniformity in federal bankruptcy. The three attributes of requisite state consent, minimal federal interference, and federal uniformity combine to result a scheme that is at once similar to and importantly distinct from corporate reorganization.

\section{Sovereignty Concerns in Later Amendments}

Subsequent amendments to municipal bankruptcy laws have reflected constant attention to the sovereignty concerns identified in both Ashton and Bekins. This section explores these amendments as applied to four separate provisions of the municipal bankruptcy laws: (1) the requirement that a municipality may be eligible for bankruptcy relief only with the consent of its state, (2) the formal restrictions on federal intrusion into governance matters, (3) the distributional priority requirements, and (4) the requirements to confirm a plan of debt adjustment.

\section{State Authorization}

Since Bekins, it had been understood that a state must consent to any federal interference with municipal control-even when that interference was narrowly focused on debt adjustment. ${ }^{77}$ The question had been whether this authorization must be explicit or whether it could be inferred. ${ }^{78}$

In the 1976 amendments to the municipal bankruptcy laws, Congress attempted to address this ambiguity by requiring that the state "generally authorize" a municipality to file bankruptcy. ${ }^{79}$ This test produced inconsistent results. Some courts found that if a state had authorized a municipality to make financial decisions on its own, then it had implicitly authorized the city to file bankruptcy. ${ }^{80}$ Accordingly, a state was deemed to have invited bankruptcy law's intrusion into its municipal governance unless it had specifically opted out. ${ }^{81}$

${ }^{77}$ But see Aaron Michael Dmiszewicki, Ashton, Bekins, and Necessity: Why Chapter 9 is Constitutional, But Not the Only Way for Municipalities to Adjust Their Debts, 23 UNIv. OF Miamı Bus. L. Rev. 59 (2016).

${ }^{78}$ See Freyberg, supra note 60 , at 1007.

${ }^{79}$ Act of April 8, 1976, Pub. L. No. 94-260, 90 Stat. 315 (1976) (codified at 11 U.S.C. $\S 401-18(1976))$.

${ }^{80}$ See Freyberg, supra note 60, at 1007; see also Juliet M. Moringiello, Specific Authorization to File under Chapter 9: Lessons from Harrisburg, 32 CAL. BANKR. J. 237, 246 (2012).

${ }_{81}$ See Freyberg, supra note 60, at 1007. 
As part of the Bankruptcy Reform Act of $1994,{ }^{82}$ the law was amended to require that a state "specifically authorize" a municipal bankruptcy filing-a result that was more protective of state interests. This change effectively shifted the municipal bankruptcy system from an "opt-out" to an "opt-in" system-a result perhaps necessary given that only Georgia ever passed an "opt-out" law. ${ }^{83}$

Under the opt-in system, twenty-seven states currently have legislation authorizing distressed municipalities to seek bankruptcy relief. ${ }^{84}$ Hence, for twenty-three states, there is no current option to address municipal insolvency through bankruptcy. ${ }^{85}$ Even in the states that have opted in, they have done so in inconsistent ways since many states have opted in conditionally. ${ }^{86}$ For example, state authorization laws may require that the governor or other state official pre-approve the municipality's plan of adjustment. ${ }^{87}$ Michigan requires several levels of review by state financial accounting boards and the governor before a city may file bankruptcy ${ }^{88}$ California requires that the entity first declare a fiscal emergency ${ }^{89}$ and Louisiana requires that the State Bond and Tax Board pre-approve a municipality's bankruptcy plan. ${ }^{90}$ Thus, even in a state that has a bankruptcy-authorizing statute, the state must take some additional step before authorizing a municipality to seek bankruptcy relief.

The result is that Chapter 9 gives significant control to states as to whether, and under what conditions, a municipality may seek bankruptcy relief, reflecting the long-held belief that the act of filing bankruptcy is a significant political decision. The corollary to this state-controlled opt-in system is that the municipal bankruptcy laws currently may provide relief only to roughly half of the states. For those states that have not opted in, their options arguably remain the same as they were in the Great Depression before Congress passed the municipal bankruptcy laws-"arguably" because, as discussed infra, the bankruptcy laws may preempt some state laws even as to the states that have not opted in to the municipal bankruptcy laws.

\section{Governmental Powers}

Two key provisions of municipal bankruptcy law are the preservation of state control and the limitation of federal intrusion into local governance. These provisions were highlighted in Bekins, have remained in force through

${ }^{82}$ Bankruptcy Reform Act of 1994, Pub. L. No. 103-394, 108 Stat. 4106 (1994) (codified as amended in 11 U.S.C. $\$ 903$ (c)(2) (2012)).

${ }^{83}$ See Freyberg, supra note 60 , at 1015 (identifying Georgia as the only opt-out state).

${ }^{84}$ See Pew Charitable Trusts, supra note 7.

${ }^{85}$ See id. at 12 (noting that Georgia and Iowa specifically prohibit the use of Chapter 9 , while the other twenty-one states simply have no authorization statute).

${ }^{86}$ See id.

${ }^{87}$ See id.

${ }^{88}$ Mich. COMP. LAWS ANN. $\S 141.1547$ (West 2016) (alternatively requiring the municipality to participate in a neutral evaluation process).

${ }^{89}$ CAL. Gov'T Code $\$ 53760.5$ (West 2016).

${ }^{90}$ La. Stat. AnN. \& 13:4741 (West 2016). 
the modern Chapter 9 of the Bankruptcy Code, and provide the statutory framework for the debt-governance divide. ${ }^{91}$

The first such provision, found now in Section 903 of the Bankruptcy Code, provides a savings clause: "This chapter does not limit or impair the power of a State to control, by legislation or otherwise, a municipality of or in such State in the exercise of the political or governmental powers of such municipality, including expenditures for such exercise . . ." ${ }^{92}$ The second, in Section 904, prohibits the bankruptcy court from interfering with local governance without the consent of the debtor:

Notwithstanding any power of the court, unless the debtor consent or the plan so provides, the court may not, by any stay, order, or decree, in the case or otherwise, interfere with-

(1) any of the political or governmental powers of the debtor;

(2) any of the property or revenues of the debtor; or

(3) the debtor's use or enjoyment of any income-producing property. ${ }^{93}$

These provisions were seen as important safeguarding features of the municipal bankruptcy laws to ensure that the restructuring would focus on a municipality's private, or business, functions, and not on its public, or governmental, functions. ${ }^{94}$

Recent scholarship has called into question whether these statutory safeguards can effectively prevent federal interference. ${ }^{95}$ Some have even questioned whether these safeguards are constitutionally mandated. ${ }^{96}$ These concerns are discussed further in Part IV.B, but for purposes of this descriptive section, it is enough to note that these provisions reflect, at the very least, an intensity of congressional concern with state sovereignty in the municipal bankruptcy context that is not evident elsewhere in the bankruptcy laws. ${ }^{97}$

${ }^{91}$ See United States v. Bekins, 304 U.S. 27, 51, 53-54 (1938).

9211 U.S.C. $\$ 903$ (2012). The addendum to this provision, added in 1946, provides an important exception, described in greater detail below, as applied to a "state law prescribing a method of composition of indebtedness." See Act of July 1, 1946, Pub. L. No. 481, ch. 532, 60 Stat. 409,415 .

${ }_{93} 11$ U.S.C. $\$ 904$ (2012). This language was included in Section 80(c)(11) of the 1934 Act and in Section 83(c) of the 1937 Act.

${ }_{94}^{4}$ See Bekins, 304 U.S. at 51, 53-54.

${ }^{95}$ See Jacoby, supra note 24, at 104-05 ("The Detroit Blueprint treats Section 904 and its consent exception as a tool of judicial oversight. While literally consistent with the text, such an interpretation illustrates how the constraints of Section 904 on federal courts are not nearly as robust as often claimed.").

${ }_{96}^{96}$ See Gillette \& Skeel, supra note 6, at 1208-16.

${ }^{97}$ See id. at 1166. 


\section{Creditor Distribution Priorities}

Unlike other areas of bankruptcy law, the municipal bankruptcy laws do not contain a comprehensive creditor distribution priority scheme. ${ }^{98}$ The original municipal bankruptcy laws contained no distribution priorities at all. ${ }^{99}$ Under that regime, courts could fashion an equitable priority for administrative expenses, but there were no explicit priority requirements. ${ }^{100}$

Such an approach was consistent with corporate bankruptcy practice, in which the Supreme Court had approved the recognition of such equitable priorities. ${ }^{101}$ In Fosdick v. Schall, a case involving an insolvent railroad, the Court upheld an equitable administrative priority for "labor, supplies, equipment, or permanent improvement of the mortgaged property as may, under the circumstances of the particular case, appear to be reasonable." 102

Later amendments to the municipal bankruptcy laws would reaffirm the understanding that Fosdick supported the use of equitable priorities in municipal bankruptcy cases. In 1976, Congress codified this administrative expense priority and added two more: debts for services or materials incurred within three months before the bankruptcy and debts to persons entitled to priority under other federal laws. ${ }^{103}$ Two years later, when Congress overhauled the whole bankruptcy code, only the administrative expense priority was retained under Chapter 9. ${ }^{104}$ The legislative history explains that the desire was not to rid municipal bankruptcy law of the second priority (which

${ }^{98}$ See Juliet M. Moringiello, Chapter 9 Confirmation Standards and the Role of State Choices, 37 CAMP. L. REv. 71, 100 (2015) [hereinafter Moringiello, Confirmation Standards] ("Very little has been written on the absence of priorities from Chapter 9, and there is no legislative history explaining their omission.").

${ }_{99}$ See Lawrence P. King, Municipal Insolvency: Chapter IX, Old and New; Chapter IX Rules, 50 Am. BANKR. L.J. 55, 58 (1976) ("Chapter IX does not incorporate any of the provisions of Chapters I to VII."). The Chandler Act priorities were found in Chapter VII, Section 64.

${ }^{100}$ See H.R. Rep. 94-686, at 28 (1975) ("Section 89 is new. There is no provision in current law for priorities. However, there are indications, such as in current Section 83(b), paragraph 4, and in Section 83(e), paragraphs 1, 2, and 3(4), that petitioners under Chapter IX regularly pay administrative expenses, or those that are incident to the confirmation and consummation of a plan.").

${ }^{101}$ See Fosdick v. Schall, 99 U.S. 235, 251-53 (1878).

${ }^{102}$ Id.

${ }^{103}$ Act of April 8, 1976, Pub L. No. 94-260, 90 Stat. 321 (1976) (codified as amended at 11 U.S.C. $\$ 409(1976)$ ):

The following shall be paid in full in advance of any distribution to creditors under the plan, in the following order:

(1) The costs and expenses of administration which are incurred subsequent to the filing of the petition under this chapter.

(2) Debts owed for services or materials actually provided within three months before the date of the filing of the petition under this chapter.

(3) Debts owing to any person, which by the laws of the United States (other than this Act) are entitled to priority.

${ }^{104}$ Bankruptcy Reform Act of 1978, Pub. L. 95-598, 92 Stat. 2549 (codified as amended at 11 U.S.C. $\$ 901$ (a) (2012)). 
would include wages earned) but to give greater flexibility to courts in determining this priority under the equitable rule of Fosdick. ${ }^{105}$

Fosdick has since been challenged in corporate bankruptcies under Chapter 11 of the Bankruptcy Code, but those challenges do not undercut its continuing applicability to municipal bankruptcy cases. ${ }^{106}$ The Seventh Circuit has held that, in the corporate context, the robust priority scheme of Chapter 11 has obviated the need (and authority) for equitable priorities. ${ }^{107}$ The logic of that case does not apply to municipal bankruptcy laws, as Chapter 9 lacks such a comprehensive priority structure. Rather, Chapter 9's minimal priority scheme seems to invite equitable priorities rather than displace them.

The plan confirmation process contemplates some sort of prioritization of claims against the municipal debtor. The municipal debtor, after all, is not required to place its creditors in the same class or to treat creditors exactly equally. Rather, the plan process permits debtors to place creditors into different classes, even when those creditors have legally similar claims. ${ }^{108}$ While the Code requires debtors to give equal treatment to all creditors within a class, it does not require equal treatment as between two separate classes. ${ }^{109}$ In fact, it permits the debtor to discriminate horizontally among classes so long as the discrimination is not "unfair." 110

Principles of equity might justify different treatment among classes, as discussed above; however, it is also possible that priorities should be based on state law. Such an approach would recognize the important state policies underlying these priorities. For example, statutory priorities may protect vulnerable claimants by granting a priority for employee wage claims; ${ }^{111}$ they may protect state interests by prioritizing bondholder claims in order to facilitate municipalities' access to the capital markets; ${ }^{112}$ and they may protect the

${ }^{105}$ See H.R. Rep. No. 95-595, at 395 (1977) ("The second [priority], for claims arising within 3 months before the case is commenced, is deleted from the statute, but may be within the court's equitable power to award, under the case of Fosdick v. Schall, 99 U.S. 235 (1878). Leaving the provision to the courts permits greater flexibility, as under railroad cases, than an absolute three-month rule.").

${ }^{106}$ See In re Kmart Corp., 359 F.3d 866, 871 (7th Cir. 2004).

${ }^{107}$ See id. ("Although courts in the days before bankruptcy law was codified wielded power to reorder priorities and pay particular creditors in the name of 'necessity' . . . today it is the Code rather than the norms of nineteenth century railroad reorganizations that must prevail .... Congress did not in terms scuttle old common-law doctrines, because it did not need to; the Act curtailed, and then the Code replaced, the entire apparatus . . . Older doctrines may survive as glosses on ambiguous language enacted in 1978 or later, but not as freestanding entitlements to trump the text.") (citations omitted).

${ }^{108}$ See 11 U.S.C. $\$ 1122(2012)$.

${ }^{109}$ See 11 U.S.C. $\$ 1123($ a)(4) (2012).

${ }^{110}$ See 11 U.S.C. \& 1129 (b)(1) (2012); Andrew B. Dawson, Pensioners, Bondholders, and Unfair Discrimination in Municipal Bankruptcy, 17 U. PA. J. Bus. L. 1 (2014) [hereinafter Dawson, Pensioners].

'I' See, e.g., In re Bentz Metal Prods. Co., Inc., 253 F.3d 283, 284 (7th Cir. 2001) (analyzing Indiana statutory protection of employees' wage claims).

${ }_{112}$ In re Sanitary \& Imp. Dist. 65 of Sarpy Cty., Neb., 873 F.2d 209, 210 (8th Cir. 1989) (analyzing application of a Nebraska statute, Neb. Rev. St. Ann. § 31-755 (West 2016), that created a priority for bondholders of state sanitary and improvement districts). 
state's revenue by prioritizing tax liabilities. Furthermore, because a plan of adjustment will determine the allocation of future revenues among creditors, deferring to state law would arguably be consistent with Section 904's prohibition against the court entering orders regarding the city's "property or revenues." 113

State law priorities, though, are generally not recognized in bankruptcy law, except to the extent those priorities are rooted in property rights. ${ }^{114}$ For better or for worse, the bankruptcy laws have nearly always displaced nonproperty-based state priority laws. ${ }^{115}$ Only once did Congress incorporate state law priorities into the Bankruptcy Code-and that was a short-lived experiment. ${ }^{116}$ The Bankruptcy Act of 1898 included non-bankruptcy priorities, but these were eliminated in the Chandler Act, right around the same time Congress was revising the original municipal bankruptcy act. ${ }^{117}$ As reflected in the legislative history to that change, state priority laws had proliferated with the result that bankruptcy estates were being entirely consumed by state law priority claims, leaving nothing for the general unsecured creditors. ${ }^{118}$ The timing of this short-lived experiment and its repeal would make it surprising to think that Congress did not consider these issues in passing the municipal bankruptcy laws.

\section{Plan Confirmation Requirements}

Although the municipal bankruptcy laws lack a robust priority scheme, the plan confirmation requirements provide some important limitations on how a municipality's plan may propose to distribute future revenues to creditors. Those plan confirmation requirements, although similar in some ways to those of Chapter 11, reflect the sovereignty concerns expressed in Bekins. First, as a procedural matter, in municipal bankruptcy only the debtor may propose a plan, whereas in corporate cases creditors are permitted to propose competing plans. ${ }^{119}$ Second, although the substantive plan confirmation requirements for municipal bankruptcy are very similar to those for confirma-

11.311 U.S.C. $\$ 904$ (2012).

${ }^{114}$ See Richard M. Hynes \& Steven D. Walt, Pensions and Property Rights in Municipal Bankruptcy, 33 Rev. Banking \& Fin. L. 609 (2014); Thomas J. Kelly, A Method of Protecting Pensions in Chapter 9: Defining the Interest As A Property Right, 89 AM. BANKR. L.J. 133, 157 (2015).

${ }^{115}$ See Hynes \& Walt, supra note 114.

${ }^{116}$ See National Bankruptcy Act of 1898, Pub. L. 55-541, 30 Stat. 544, $563 \$ 64(\mathrm{~b})(5)$ (1898); see also David Skeel, What is a Lien? Lessons from Municipal Bankruptcy, 2015 U. ILL. L. Rev. 675, 682 ("As originally enacted, the 1898 Act incorporated any nonbankruptcy priorities that were honored under state or federal law. Concerned that there was little or nothing left for general unsecured creditors in most cases after state law priorities were satisfied, lawmakers largely eliminated state law priorities under the Chandler Act of 1938, which made major changes to the 1898 Act.").

${ }^{117}$ See Skeel, supra note 116 , at 682.

${ }_{118}^{18}$ See id.

11911 U.S.C. § 1121 (2012). 
tion of a corporate reorganization plan, ${ }^{120}$ the way courts have interpreted and applied these requirements in municipal bankruptcy highlights the sovereignty concerns that distinguish municipal bankruptcy federalism. This section will focus on three key requirements that illustrate the differences between municipal and corporate reorganization: the best interests test, ${ }^{121}$ the feasibility test, ${ }^{122}$ and the unfair discrimination test. ${ }^{123}$ These three requirements highlight the roles of state and bankruptcy law in determining how a municipal debtor may allocate its future revenues.

A court may confirm a Chapter 9 plan of adjustment if, inter alia, "the plan is in the best interests of creditors." 24 This "best interests test" is not defined in Chapter 9; however, it is a term of art in Chapter 11 corporate reorganizations. ${ }^{25}$ In the Chapter 11 context, courts have interpreted this as requiring that the plan provide each creditor at least as much under the reorganization plan as it would have received if the estate were liquidated. ${ }^{126}$ In the municipal context, there is no liquidation alternative. Accordingly, courts have considered this test to require that the Chapter 9 plan of adjustment provide creditors with at least as much as they would have received under state law. ${ }^{127}$ State law thus provides the baseline for determining the sufficiency of the bankruptcy plan. This opens the door for state law priorities to shape the bankruptcy plan. ${ }^{128}$

${ }^{120}$ See Moringiello, Confirmation Standards, supra note 98, at 78; 11 U.S.C. $\S 901$ (2012) (directly incorporating four of the fifteen requirements that Section 1129(a) imposes on consensual plan (i.e., plans approved by all classes of creditors)); 11 U.S.C. $\$ 943$ (2012) (using the terms "best interests" and "feasible," which are both Chapter 11 terms of art).

${ }^{121}$ See 11 U.S.C. $\$ 943(\mathrm{~b})(7)$.

${ }^{122}$ See id.

${ }_{123} 11$ U.S.C. $\$ 901$ (a) (incorporating 11 U.S.C. \$ 1129(b)(1) (2012)).

12411 U.S.C. $\$ 943(\mathrm{~b})(7)$.

12511 U.S.C. $\$ 1129(\mathrm{a})(7)$ (2016), provides in full:

(7) With respect to each impaired class of claims or interests-

(A) each holder of a claim or interest of such class-

(i) has accepted the plan; or

(ii) will receive or retain under the plan on account of such claim or interest property of a value, as of the effective date of the plan, that is not less than the amount that such holder would so receive or retain if the debtor were liquidated under Chapter 7 of this title on such date.

${ }^{126}$ See Collier on Bankruptcy, fl 1129.02 (Alan N. Resnick \& Henry J. Sommer eds., 16th ed. 2016).

${ }^{127}$ See In re Corcoran Hosp. Dist., 233 B.R. 449, 454 (Bankr. E.D. Cal. 1999) (finding plan to satisfy the best interests test when the plan offered more than could be accomplished otherwise); In re Sanitary \& Imp. Dist., No. 7, 98 B.R. 970, 974 (Bankr. D. Neb. 1989) (best interests requires a finding that "the plan as proposed is better than the alternatives"); In re Pierce Cty. Hous. Auth., 414 B.R. 702, 718 (Bankr. W.D. Wash. 2009) ("The "best interest of creditors' requirement of $\S 943(\mathrm{~b})(7)$ is 'generally regarded as requiring that a proposed plan provide a better alternative for creditors than what they already have." ) (quoting In re Mount Carbon, 242 B.R. 18, 34 (Bankr. D. Co. 1999)).

${ }_{128}$ See C. Scott Pryor, Municipal Bankruptcy: When Doing Less Is Doing Best, 88 AM. BANKR. L.J. 85, 121 (2014) ("The best interests test resuscitates the question of state-law fairness."). 
In a similar manner, Chapter 9 incorporates Chapter 11's feasibility requirement without definition or guidance. ${ }^{129}$ As with the "best interests test," Chapter 11 does not actually use the word feasibility. Rather, this is the common name for the statutory requirement that " $[c]$ onfirmation of the plan is not likely to be followed by the liquidation, or the need for further financial reorganization, of the debtor or any successor to the debtor under the plan, unless such liquidation or reorganization is proposed in the plan." 130 Chapter 9 simply requires the court to find the plan to be "feasible." 31 In both Chapters 9 and 11 , the feasibility test requires the court to assess the viability of the proposed plan; however, as Moringiello has explained, the unique nature of municipalities as both private issuers of debt and public service providers requires courts to apply a special assessment in municipal bankruptcy cases. ${ }^{132}$ In Chapter 9, the feasibility assessment has been interpreted as evaluating whether the debtor can make its proposed debt payments while still providing the essential public services. ${ }^{133}$

Finally, Chapter 9 incorporates most of Chapter 11's "cram down" provisions for confirming a plan over the dissent of an opposing class of creditors. These provisions-incorporated directly into Chapter 9-provide a protection for the dissenting class of creditors: if the majority of any class of creditors opposes the plan, the court can nonetheless confirm the plan if the plan does not "unfairly discriminate" against the dissenting class. ${ }^{134}$ This test has been described as requiring horizontal parity. ${ }^{135}$ Among creditors at the same level of priority, the plan must treat them roughly the same. Treatment may differ but not in a way that is unfairly discriminatory. While some have argued that this test should be interpreted identically in both corporate and municipal contexts, ${ }^{136}$ others have argued that the test requires assessing the differing treatments within the context of municipalities' political functions. ${ }^{37}$ Differing treatment may be tolerated to the extent it reflects governance policies.

These confirmation standards highlight the unique federalism relationship in municipal bankruptcy. Unlike preemption analyses that may result in federal law displacing, in full or in part, state laws, the confirmation standards reflect a dual role for federal and state law. Even though federal law provides the rules for plan confirmation, these confirmation rules leave significant room for state law. Thus, state law may play an important role in

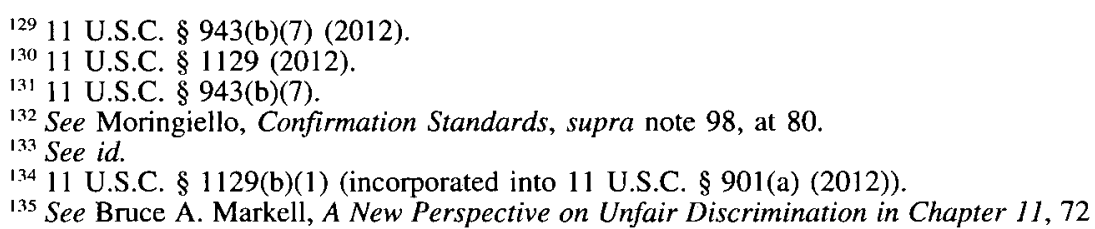
AM. BANKR. L.J. 227, 227-28 (1998) ("[U]nfair discrimination is best viewed as a horizontal limit on nonconsensual confirmation, in contrast to the vertical limit imposed by the requirement that a nonconsensual plan be 'fair and equitable." ").

136 See, e.g., Hynes \& Walt, supra note 114, at 637-38.

${ }^{137}$ See, e.g., Moringiello, Confirmation Standards, supra note 98, at 84; Dawson, Pensioners, supra note 110. 
applying the federal bankruptcy laws. At the same time, these confirmation standards not only invite state participation into the debt side of the equation, but they also create an opportunity for the bankruptcy court to have a role in the operational side. ${ }^{138}$ McConnell and Picker described this as creating the potential for "judicial control by a wink and a nod," as a court could refuse to confirm a plan unless, for example, the city promised to raise taxes. ${ }^{139}$

Although certainly not exhaustive, a review of these confirmation requirements shows how these standards reflect a municipal bankruptcy federalism that, while similar in some ways to bankruptcy federalism questions, is importantly distinct in others. Even though the language of the confirmation requirements in Chapters 9 and 11 are similar, the requirements reflect deeper sovereignty concerns in the municipal bankruptcy context.

\section{Uniformity}

Thus far, the background on municipal insolvency law has highlighted a persistent concern with state sovereignty; however, there has been an equally persistent countervailing concern with federal supremacy. While the sovereignty concerns provide the background for the governance side of the Great Divide Model, the uniformity concern motivates the debt side.

The uniformity-side of this equation arises from the language of the Bankruptcy Clause, which gives Congress the power to enact "uniform laws on the subject of bankruptcies." The significance of "uniform law" has posed problems since the Marshall Court: to what extent does uniformity displace state debtor-creditor laws. ${ }^{140}$ In the municipal bankruptcy context, the question is whether the enactment of "uniform" municipal bankruptcy laws preempts state laws that would attempt to restructure municipalities' finances.

Although Congress's constitutional authority to enact "uniform laws on the subject of bankruptcies" might suggest that the federal government has a monopoly on bankruptcy laws, the Court has found that states may pass bankruptcy laws, so long as those laws do not unconstitutionally impair the obligation of contracts or conflict with federal bankruptcy laws. The states

${ }^{138}$ See Vincent S. J. Buccola, Law and Legislation in Municipal Bankruptcy, Cardozo L. REv. (forthcoming), http://dx.doi.org/10.2139/ssrn.2534856 [https://perma.cc/RH5E-JPJC]; McConnell \& Picker, supra note 23 (arguing that courts could use the best interests test to indirectly force operational changes).

${ }^{139}$ McConnell \& Picker, supra note 23.

${ }^{140}$ See Stephen J. Lubben, Puerto Rico and the Bankruptcy Clause, 88 AM. BANKr. L.J. 553, 563 (2014) (describing how a series of cases beginning in the Marshall Court considered, but consistently rejected, "the proposition that the Clause takes bankruptcy and insolvency away from the States"); Judith Schenck Koffler, The Bankruptcy Clause and Exemption Laws: A Reexamination of the Doctrine of Geographic Uniformity, 58 N.Y.U. L. REv. 22, 22 (1983) ("The interpretation of the constitutional provision empowering Congress to make uniform Laws ... on the subject of Bankruptcies' has defied principled interpretation since its adoption and continues to be a source of analytical confusion, particularly in the area of bankruptcy exemptions."). 
retain the power to pass bankruptcy laws. ${ }^{141}$ Thus, during most of the nineteenth century when there was no federal bankruptcy law in place, bankruptcy legislation was entirely in the realm of state law. ${ }^{142}$

During those periods in which there was no federal bankruptcy law, the primary limitation on state bankruptcy laws was the Contracts Clause, which invalidated states laws purporting to discharge prior debts; however, state bankruptcy laws could discharge debts incurred after the law's enactment. ${ }^{143}$

When Congress passed what would become the first permanent bankruptcy law in 1898, however, that law was held to preempt state laws within its field. Thus, states could no longer discharge debts at all, whether prospectively or retrospectively. ${ }^{144}$ Aside from that limitation, though, there was uncertainty about when a state debtor-creditor law fell within the scope of the federal bankruptcy laws.

When Congress passed the first municipal bankruptcy laws, this likewise raised the question of preemption: to what extent did the municipal bankruptcy laws preempt state local rescue laws? The Court addressed the question in Faitoute Iron \& Steel Co. v. City of Asbury Park. ${ }^{145}$

In Faitoute, the Court considered the constitutionality of a New Jersey state law designed to address municipal financial distress. ${ }^{146}$ New Jersey had attempted to restructure the debts of Asbury Park under state law-a process New Jersey had begun while awaiting the revised municipal bankruptcy law. ${ }^{147}$ Under the New Jersey statute, the city proposed a plan to refund its outstanding bonds for new bonds, extending the maturity date and lowering the interest rate..$^{148}$ The city obtained the approval of eighty-five percent of its bondholders; however, a group of dissenters opposed the plan and appealed to the Supreme Court, arguing that the New Jersey statute unconstitutionally impaired the obligation of contracts and that the new municipal bankruptcy law preempted this state rescue law-i.e., that Congress had seized control over municipal insolvency, thus suspending New Jersey's law. ${ }^{149}$

The Court rejected this monopolization argument. ${ }^{150}$ In an opinion by Justice Frankfurter, the Court found that the municipal bankruptcy lawseven if they applied to the bonds issued before those laws were enacted-

141 See Lubben, supra note 140.

${ }^{142}$ See David A. Skeel, Jr., Rethinking the Line Between Corporate Law and Corporate Bankruptcy, 72 Tex. L. Rev. 471 (1994).

${ }^{143}$ See Sturges v. Crowninshield, 17 U.S. 122, 135-36 (1819) (retroactive application of a state bankruptcy law to previously incurred debts was an unconstitutional impairment of the obligation of contracts); Ogden v. Saunders, 25 U.S. 213, 368-69 (1827) (prospective application of a state bankruptcy law did not impair the obligation of contracts).

144 See Pobreselo v. Joseph M. Boyd Co., 287 U.S. 518, 525-26 (1933) (upholding a Wisconsin assignment law that, even though similar to bankruptcy law in some ways, was "quite in harmony with the purposes of the federal [bankruptcy] act").

${ }^{145}$ See Faitoute Iron \& Steel Co. v. City of Asbury Park, 316 U.S. 502, 507 (1942).

${ }^{146} \mathrm{Id}$.

${ }_{147}^{14}$ Id. at 504.

${ }_{148}$ Id. at 507.

${ }^{149} \mathrm{Id}$.

${ }^{150} \mathrm{Id}$. at 508 . 
did not suspend the New Jersey statute. ${ }^{151}$ Frankfurter reasoned that the municipal bankruptcy law had been "carefully drawn so as not to impinge on the sovereignty of the State. The State retains control of its fiscal affairs. The bankruptcy power is exercised ... only in a case where the action of the taxing agency in carrying out a plan of composition approved by the bankruptcy court is authorized by state law." 152 Here, New Jersey had not authorized Asbury Park to file bankruptcy. Consequently, he concluded that the federal municipal bankruptcy laws could have not preemptive effect on the New Jersey statute. ${ }^{153}$

Because Congress had carefully limited the revised bankruptcy laws in order to protect state sovereignty, New Jersey retained the power to adjust debts, provided it did so without unconstitutionally impairing the obligation of contracts. ${ }^{154}$ Thus, following Faitoute, the patchwork of state financial rescue laws continued, at least as applied to those states that had, like New Jersey, not opted in to the municipal bankruptcy option. The municipal bankruptcy laws did not shift control over municipal bankruptcy to the federal government; rather, control remained with the states. Uniformity thus gave way to state sovereignty.

Congress immediately sought to overrule Faitoute in order to create a uniform system of municipal bankruptcy. ${ }^{155}$ Section 83(i) of the Act, which had previously served the significant role of ensuring that federal bankruptcy law would not impede a state's ability to control its municipalities, was amended by adding the following italicized language:

Nothing contained in this chapter shall be construed to limit or impair the power of any State to control, by legislation or otherwise, any political subdivision thereof in the exercise of its political or governmental powers, including expenditures therefor; Provided, however, That no state law prescribing a method of composition of indebtedness of such agencies shall be binding upon any creditor who does not consent to such composition, and no judgment shall be entered under such State law which would bind a creditor to such composition without his consent. ${ }^{156}$

The House Report explained that this amendment was intended to preempt state bankruptcy laws seeking to bind nonconsenting creditors, reflecting a monopolization policy: "[A] bankruptcy law under which bondholders

151 Id.

${ }^{152}$ Id. (quoting United States v. Bekins, 304 U.S. 27, 50-51 (1938)).

${ }^{153} \mathrm{Id}$. at 508-09 ("Can it be that a power that was not recognized until 1938, and when so recognized, was carefully circumscribed to reserve full freedom to the states, has now been completely absorbed by the federal government-that a state which, as in the case of New Jersey, has after long study devised elaborate machinery for the autonomous regulation of problems as peculiarly local as the fiscal management of its own household, is powerless in this field? We think not.").

${ }^{154} I d$. at $512-13$.

${ }^{155}$ Act of July 1, 1946, Pub. L. No. 481, ch. 532, 60 Stat. 409, 415.

${ }^{156} \mathrm{Id}$. 
of a municipality are required to surrender or cancel their obligations should be uniform throughout the 48 States . . .."157

While this amended language is widely acknowledged as overruling Faitoute and increasing federal control in this arena, there are reasons to doubt its effectiveness. ${ }^{158}$ As an initial matter, it is not at all clear that it would have actually applied to the New Jersey statute, as that statute arguably imposed a "debt adjustment" and not a "composition." 159 Debt composition laws affect the principal amount of indebtedness; debt adjustment laws modify repayment terms, such as interest rates and maturity dates. ${ }^{160}$ The New Jersey statute, as described in Faitoute, specifically prohibited adjusting the principal, thus making it likely a debt adjustment law, not a composition law. ${ }^{161}$

The uncertain scope of this adjustment/composition distinction arose again in the financial crisis of New York City in the 1970s. ${ }^{162}$ Municipal bankruptcy law at that time was perceived as unworkable for large cities, and so the state of New York addressed the city's insolvency under state law. One such response was to pass the New York State Emergency Moratorium Act, which suspended payment on certain city debts. ${ }^{163}$ Challengers asserted that the Act was a debt composition law, thus preempted by Section 83.164 The court in Ropico, Inc. v. City of New York rejected this, holding that the New York law imposed an "extension and not a proscribed composition."165

The New York City crisis prompted Congress to revisit the municipal bankruptcy laws, making those laws better suited for large cities. As part of that effort, there were proposals to remove the preemption language in Section 83(i) altogether. ${ }^{166}$ This would have undermined the goal of national uniformity; however, it was suggested that non-uniformity might be outweighed by "the interests of the States in the management of their own fiscal affairs." 167 The draw of uniformity, however, ultimately prevailed. Congress retained this language, explaining that it "was enacted in response to, and overruled the holding of the Supreme Court in [Faitoute]," and then quoting the 1946 House Report language discussing the need for national uniformity. ${ }^{168}$

${ }^{157}$ H.R. Rep. No. 2246, 79th Cong., 2d Sess. at 24 (1946); see also U.S. Code CONGRESSIONAL SERVICE, 1246-49 (1946).

${ }_{158}$ See Freyberg, supra note 60, at 1012 ("Congress, however, disagreed with the Supreme Court and enacted what is now Section 903 . Section 903 prevents state authorization of compositions of indebtedness which are binding on non-consenting creditors. Congress' stated purpose in enacting this section was to ensure equal treatment of municipal bondholders throughout the nation.").

${ }_{159}$ See Lubben, supra note 140 , at 570.

${ }^{160}$ See id. at 570 n.109 (defining composition laws).

161 See id. at 570.

${ }^{162}$ See Ropico, Inc. v. City of New York, 425 F. Supp. 970, 972 (S.D.N.Y. 1976).

${ }_{163}$ See id.

${ }_{164}^{164}$ See id. at 978.

${ }^{165} \mathrm{Id}$. at 983.

${ }^{166}$ See H.R. ReP. No. 94-686, at 2 (1975).

${ }^{167} \mathrm{ld}$.

${ }^{168} I d$. 
Congress again flirted with deleting this language when it overhauled the bankruptcy laws in the Bankruptcy Reform Act of 1978, which relabeled Chapter IX as Chapter 9 and moved Section 83(i) to Section 903(1). ${ }^{169}$ The House Report explains that, in light of the now-overruled decision of $\mathrm{Na}$ tional League of Cities v. Usery, ${ }^{170}$ legislators discerned that the Supreme Court might be increasingly sensitive to federal court interference with state control. ${ }^{171}$ It was thought removing the provision would preserve the constitutionality of Chapter 9 by "recogniz[ing] the power of the States to assist municipal work-outs short of bankruptcy court."172

Despite this concern, Congress retained the preemption language, continuing to express the goal of creating a uniform system for municipal insolvency. The Senate Report explained the need to retain the preemption language: "Deletion of the provision would 'permit all states to enact their own versions of Chapter IX' . . which would frustrate the constitutional mandate of uniform bankruptcy laws." 173

Accordingly, even though Congress has consistently expressed concern that municipal bankruptcy laws not interfere with state control over municipal governance, it has also sought to ensure that federal law provides the only way to adjust municipal debts. These competing concerns provide the foundation for the Great Divide Model. Leaving governance matters to the states respects state sovereignty; concentrating debt adjustment matters in federal bankruptcy law respects federal superiority.

The case studies in the following part describe the way these dynamics have played out in recent high-profile municipal insolvency crises. They also highlight the flaw in trying to balance these competing concerns by categorizing matters as governance- or debt-related.

\section{Municipal Bankruptcy Federalism: The Great Divide Model}

As described in the previous part, municipal bankruptcy law has tried to balance the interests of state sovereignty and of federal supremacy. This part uses case studies to describe the dominant model courts have used to analyze these federalism issues: the Great Divide Model. Matters that are debt-related belong exclusively in the federal sphere; those that are governancerelated belong in the state sphere. This formalist approach thus treats federalism matters as definitional matters. The key is to define the power at question.

The federalism concerns have arisen in two principal contexts. First, courts have had to analyze the preemptive scope of Chapter 9 , in other words, the extent to which Congress has left room for states to address mu-

\footnotetext{
${ }^{169}$ Bankruptcy Reform Act of 1978, Pub. L. No. 95-598, 92 Stat. 2549 (1978).

170426 U.S. 833 (1976).

171 See H.R. REP. No. 95-595, at 5964 (1977).

${ }^{172}$ Id.

${ }^{173}$ S. Rep. No. 95-989, at 109 (1978).
} 
nicipal insolvency. That issue is discussed in Section A of this part, which frames the analysis through two case studies involving Pontiac, Michigan, and Puerto Rico. Second, courts have had to consider the ability of federal law to "leak" into governance matters, an issue discussed in Section B, which frames the analysis through case studies involving Stockton, California, and Detroit.

While these cases illustrate the Great Divide Model, they also highlight the descriptive and normative flaws in the model. Descriptively, the Great Divide Model fails because it is not always possible to categorize matters as exclusively governance- or debt-related. Normatively, it fails because it obscures the tradeoffs between federal supremacy and state control in the municipal insolvency framework. It has permitted federal intervention into local governance matters that are at least partly financial in nature, without considering the impact on state sovereignty. This model of federalism permits the expansion of federal power in this context, and it fails to provide an analytical framework to consider the costs of such expansion.

\section{A. State Law Alternatives}

The first context in which courts have analyzed municipal bankruptcy federalism is in those cases in which states have attempted to resolve municipal financial distress under state law-that is, without resorting to bankruptcy relief. Following Faitoute and the enactment of Section 83(i), now Section 903(1), it is clear that once a state opts in to the municipal bankruptcy relief, it can no longer use state law to impose a debt adjustment plan. ${ }^{174}$ Some have expressed doubts, though, as to this preemptive scope: does Section 903(1) likewise preempt state composition laws for states that have not opted in? ${ }^{175}$ And how broad is that preemptive scope, as debt "composition" laws may be much narrower than characterized by the statute's legislative history? ${ }^{176}$

Despite these concerns, the case studies below illustrate that courts have characterized Congress's power to pass bankruptcy laws as an exclusive one. Employing the Great Divide's formalist approach, these courts have sidestepped the potentially larger constitutional concerns arising from this increase in federal power, such as whether courts are impermissibly intruding upon state sovereignty.

${ }^{174}$ See Lubben, supra note 140, at 570-71 (" $[I] \mathrm{t}$ seems clear that for states that have opted in to Chapter 9 , the chapter becomes the sole means of addressing municipal financial distress.").

${ }_{175}$ See id.; see also David A. Skeel, Jr., States of Bankruptcy, 79 U. CHI. L. Rev. 677, 730 n.230 (2012) (noting this uncertainty).

176 See Lubben, supra note 140, at 570. 


\section{Case Study: Pontiac, $M I$}

Pontiac, Michigan, illustrates the potential for the Great Divide Model to permit federal intervention into municipal governance matters even when the municipality has not filed bankruptcy. Michigan has received significant attention for its use of emergency managers - most of it negative, especially based on the tragic situation in state-controlled Flint. ${ }^{177}$ While Flint's case may call into question the effectiveness of state law interventions, that of Pontiac called into question whether bankruptcy law limits the reach of such state laws even as to cities that have not filed bankruptcy.

Michigan's Local Financial Stability and Choice Act permits the governor to appoint an emergency manager to assume control over financially distressed cities. ${ }^{178}$ The emergency manager may attempt to address the fiscal crisis under state law or recommend that the governor authorize a bankruptcy filing. With the city of Pontiac, the emergency manager has attempted to restructure the city's finances without seeking federal bankruptcy relief; however, as discussed in this section, the Sixth Circuit has suggested thateven though Pontiac has not filed bankruptcy or received state authorization to do so-Section 903(1) of the Bankruptcy Code may limit Michigan law. ${ }^{179}$

Pontiac was placed under the control of a state-appointed emergency manager in March 2009. ${ }^{180}$ The emergency manager was authorized to take over all financial decisions, amend budgets, renegotiate labor contracts, and reorganize departments in order to address the city's significant budget deficit. ${ }^{181}$ Although Michigan law permits the emergency manager to file bankruptcy if authorized by the governor, the emergency manager sought to address the city's problems outside of bankruptcy. ${ }^{182}$ Thus, no bankruptcy was ever authorized or filed.

Beginning in 2011, the emergency manager issued a series of orders to reduce and eliminate public retirees' health care benefits. ${ }^{183}$ The retirees challenged this move on two grounds: (1) such a modification would unconstitutionally impair their contractual rights, and (2) the emergency manager's power was suspended by Chapter 9.184

${ }^{177}$ See Julie Bosman \& Monica Davey, Anger in Michigan over Appointment Emergency Managers, N.Y. Times (Jan. 22, 2016), http://www.nytimes.com/2016/01/23/us/anger-in-michigan-over-appointing-emergency-managers.html?_r=0 [https://perma.cc/L3AK-EGFV]. 147.1558

${ }^{178}$ Local Financial Stability and Choice Act, Act 436 of 2012, Мich. Comp. Laws $\S$

${ }^{179}$ See Pontiac Retired Emps. Ass'n v. Schimmel, 751 F.3d 427, 429-31 (6th Cir. 2014) (per curiam).

${ }^{180}$ See Catherine Jun, State Takes Over Pontiac Finances, Detrolt News, Mar. 20, 2009, 2009 WLNR 17079909.

${ }^{181}$ See id.

182 See Local Financial Stability and Choice Act, Act 436 of 2012, Mich. Comp. Laws $\S$ 147.1558 (empowering emergency manager to recommend to the governor that the municipality be authorized to file a petition for bankruptcy relief).

${ }^{183}$ See Schimmel, 751 F.3d at 429.

${ }^{184}$ See id. at $430-31$. 
The Sixth Circuit, sitting en banc, ruled in a per curiam decision that the health care modifications may violate the Contracts Clause and suggested that they may also be expressly preempted by Chapter $9 .{ }^{185}$ Section 903(1) of the Bankruptcy Code, according to the court, may displace state laws even if the city has not sought bankruptcy protection, if such state law would effect "a method of composition of indebtedness that binds the retirees without their consent." 186 It then remanded to consider all the relevant factors for determining the retirees' Contracts Clause and due process claims. ${ }^{187}$

Judge McKeague concurred in the ruling but wrote separately to address the Section 903 argument. He cautioned that Section 903(1) may not necessarily preempt all state laws as it could be read more narrowly to preempt state composition laws only when Chapter 9 is invoked. ${ }^{188}$ In support of this narrower interpretation, he noted that the preemption language should be read in its context as an exception to Section 903's savings clause. That savings clause applies only when Chapter 9 is invoked. Therefore, the preemption language might also apply only when Chapter 9 is invoked. ${ }^{189}$

The court's ruling is consistent with the Great Divide Model: to the extent the emergency manager attempts to adjust debts over the opposition of creditors, this belongs in the exclusive power of the bankruptcy laws. At the same time though, this holding is quite jarring when applied to states that have not authorized a bankruptcy filing. Consider what Michigan's power would have looked like without a federal municipal bankruptcy law: just like states during the Great Depression, Michigan would have had to craft a plan that would reduce debts without unconstitutionally impairing the obligation

${ }^{185} \mathrm{Id}$. at 431 ("[T]he plain language of this section is not limited to bankruptcy proceedings. The retirees' Bankruptcy Code claim turns on whether Public Act 4 (or Public Act 436, to the extent relevant on remand) prescribes a method of composition of indebtedness that binds the retirees without their consent and, if so, whether principles of state sovereignty preclude application of $\S 903(1)$ in this case.").

${ }^{186} \mathrm{Id}$. The full text of Section 903 reads:

This chapter does not limit or impair the power of a State to control, by legislation or otherwise, a municipality of or in such State in the exercise of the political or governmental powers of such municipality, including expenditures for such exercise, but-

(1) a State law prescribing a method of composition of indebtedness of such municipality may not bind any creditor that does not consent to such composition; and

(2) a judgment entered under such a law may not bind a creditor that does not consent to such composition.

11 U.S.C. $\$ 903$.

${ }_{187}$ Schimmel, 751 F.3d at 433.

${ }^{188}$ Id. ("[S]ubsection (1) is an exception to the general proposition that Chapter 9 does not limit or impair State power. The exception appears to reflect congressional intent that where Chapter 9 is invoked, it does operate to limit or impair State power in relation to the specific type of State law described in subsection (1). Viewed in context, then, the plain language of $\S$ 903(1) may be construed to mean, and today's opinion should not be read to foreclose the possibility, that $\S 903(1)$ represents a specific limitation on State power only where Chapter 9 has been invoked.").

${ }^{189}$ See id. at $433-34$. 
of contracts. Following the Sixth Circuit's ruling, though, states that have chosen not to use the municipal bankruptcy laws are actually in a worse situation. Their powers are limited not only by the Contracts Clause but also by a bankruptcy law that they have elected not to use.

The Sixth Circuit reached this result under a plain reading of Section 903(1) of the Bankruptcy Code, without considering whether such limitation of state power-without state consent-would be constitutional. While the court's ruling is arguably consistent with the legislative purpose of Section 903(1), it does not consider whether such non-consensual centralization of power unconstitutionally intrudes upon state sovereignty.

\section{Case Study: Puerto Rico's Recovery Act}

This dynamic has also played out-albeit with many sui generis characteristics-in Puerto Rico's attempt to restructure the debts of its public corporations under Puerto Rican law. As described in this section, Puerto Rico, unlike the fifty states, cannot authorize its municipalities to file bankruptcy. This constraint left open the question, on which the Supreme Court recently ruled, as to whether the municipal bankruptcy laws nonetheless limited Puerto Rico's ability to address its financial crisis on its own.

Puerto Rico lost its investment bond rating in 2014, at which point it was described as a "behemoth" among non-sovereign government borrowers, "with roughly $\$ 60$ billion of direct and indirect obligations outstanding, with another $\$ 10$ billion in limited obligations." 190 Since then, this debt has ballooned to over $\$ 71$ billion in public debt. ${ }^{191}$ A considerable portion of this debt-around thirty billion dollars-is owed by the Commonwealth's public agencies that supply public services such as the water and electricity authorities. ${ }^{192}$ The Puerto Rico Electric Power Authority, or PREPA, with over nine billion dollars in debt, has received the majority of the attention, as it is the focus of litigation with U.S. hedge fund investors. ${ }^{193}$

Even though Chapter 9 of the Bankruptcy Code recognizes Puerto Rico as a "state," Chapter 9 makes Puerto Rican municipalities ineligible for bankruptcy relief. ${ }^{194}$ For reasons unknown, Congress excluded Puerto Rico in

${ }^{190}$ Tom Tzitzouris, Why Would a Puerto Rico Debt Crisis Matter?, Forbes (Oct. 16, 2013), http://www.forbes.com/sites/realspin/2013/10/16/why-would-a-puerto-rico-debt-crisismatter/.

191 See Dep't of Treasury, Puerto Rico's Economic and Financial Crisis, https:// www.treasury.gov/connect/blog/Documents/Puerto_Ricos_fiscal_challenges.pdf [https://per ma.cc/CG9P-3PFZ].

${ }^{192}$ Fed. Res. Bank of N.Y., An Update on the Competitiveness of Puerto Rico's ECONOMY (July 31, 2014), https://www.newyorkfed.org/outreach-and-education/puerto-rico/ 2014/report-main.html [https://perma.cc/4YKM-JKLM] (listing the amount as twenty-four billion dollars); Robert Rasmussen, Puerto Rico: Of Capital Structures, Control Rights and Liquidity, CAP. MKTS. L. J. 14 (forthcoming 2016) (listing the amount as around thirty billion dollars).

${ }^{193}$ See, e.g., Franklin Cal. Tax-Free Tr. v. Puerto Rico, 805 F.3d 322 (1st Cir. 2015).

19411 U.S.C. \& 101(52) (2012) ("The term 'State' includes the District of Columbia and Puerto Rico, except for the purpose of who may be a debtor under chapter 9 of this title."); see also Lubben, supra note 140. 
the Bankruptcy Amendments and Federal Judgeship Act of 1984. ${ }^{195}$ This has left Puerto Rico without the option of using Chapter 9 to address the fiscal distress of its municipalities and public corporations.

Although the states have the authority to use bankruptcy law to adjust the debts of public corporations under Chapter 9, Congress has denied such an option to Puerto Rico. With no bankruptcy relief available, Puerto Rico attempted to address the insolvency of its municipalities under Puerto Rican law, drafting a commonwealth law that is intentionally and expressly similar to Chapter 9 of the Bankruptcy Code. ${ }^{196}$ The Puerto Rico Public Corporation Debt Enforcement and Recovery Act ${ }^{197}$ (the "Recovery Act") would provide a means to impose a debt adjustment plan on creditors, just as would be possible under Chapter 9.

This law, however, was immediately challenged by PREPA bondholders and found to be preempted by the bankruptcy laws. ${ }^{198}$ The First Circuit, in upholding that decision, held that Congress has the power to extend Chapter 9 to Puerto Rico but has declined to do so-that is, Congress "preserved to itself that power to authorize Puerto Rican municipalities to seek Chapter 9 relief"-thereby preempting Puerto Rico's attempt to approximate Chapter 9 relief under commonwealth law. 199

The Supreme Court recently ruled on this preemption matter, holding that Section 903(1) has statutorily preempted the Recovery Act. ${ }^{200}$ Even though Congress exempted Puerto Rico from bankruptcy eligibility, the Court found that Puerto Rico is still a "state" as defined in the Bankruptcy Code. ${ }^{201}$ Thus, Section 903(1)'s language that "a State law prescribing a method of composition of indebtedness of such municipality may not bind any creditor that does not consent to such composition" would apply to all "states," including Puerto Rico. ${ }^{202}$ In other words, the Court interpreted the preemption language in Section 903(1) as creating an exclusively federal

${ }^{195}$ Bankruptcy Amendments and Federal Judgeship Act of 1984, Pub. L. No. 98-353, 98 Stat. 333 (codified as amended at 11 U.S.C. § 101(52)); see also Lubben, supra note 140, at 572 (noting that the exclusion happened as part of a much larger change to the bankruptcy laws in response to the Supreme Court's decisions in N. Pipeline Const. Co. v. Marathon Pipe Line Co., 458 U.S. 50 (1982) and NLRB v. Bildisco \& Bildisco, 465 U.S. 513 (1984), and so most of the legislative history dealt with that overhaul).

${ }^{196}$ Puerto Rico Public Corporation Debt Enforcement and Recovery Act, Act No. 71 (June 28, 2014), at 173, makes clear its intent to copy Chapter 9 of the Bankruptcy Code:

In designing chapter 3 , this Legislative Assembly has adopted a model similar to that of chapter 9 of title 11 of the United States Code in order to provide all stakeholders with much needed familiarity in a process wrought with uncertainty. As a result, this Legislative Assembly clearly expresses its intent that jurisprudence interpreting the provisions of chapter 9 of title 11 of the United States Code be used, to the extent applicable, for purposes of interpreting the provisions of chapter 3 of this Act.

${ }^{197}$ Id.

${ }_{198}$ See generally Franklin Cal. Tax-Free Tr. v. Puerto Rico, 805 F.3d 322 (1st Cir. 2015).

${ }^{199} \mathrm{Id}$. at 325.

${ }^{200}$ Puerto Rico v. Franklin Cal. Tax-Free Tr., 136 S. Ct. 1939, 1945 (2016).

${ }^{201} I d$.

${ }^{202} I d$. 
remedy for addressing municipal debt restructuring. As Justice Thomas wrote, "The Federal Bankruptcy Code pre-empts state bankruptcy laws that enable municipalities to restructure their debts over the objection of creditors and instead requires municipalities to restructure such debts under Chapter 9 of the Code." 203

The Court found this result to be dictated by the plain meaning of the statute. However, as the dissent argued, such a result is inconsistent with the overall structure of Section 903 and Chapter 9.204 After all, Section 903 was designed as a savings clause, ensuring that states would remain in control over governance matters in a Chapter 9 case. As such, it would seem to apply only to those debtors that had actually commenced a Chapter 9 caseotherwise, there would be no concern about federal intervention in governance matters. ${ }^{205}$ Unless and until the state authorizes its municipality to file bankruptcy, there would be no threat of federal intervention and hence no need for Section 903's savings clause. Accordingly, it would not make sense to apply Section 903 at all to Puerto Rican municipalities that are excluded from Chapter 9 relief.

Although Puerto Rico is sui generis in some ways-namely, because of its commonwealth status ${ }^{206}$ and because only it and the District of Columbia are excluded from Chapter 9 eligibility-Puerto Rico's attempted local rescue law highlights the interaction of state and federal level control over distressed municipalities. The opinion's recitation of an exclusive power to restructure municipal debts reflects the one of the core tenets of the Great Divide Model: only federal law can restructure debts. Finally, it shows how such an assumption of federal uniformity limits state control over local governance.

\section{B. Debt-Governance Divide?}

Whereas the prior section examined how the Great Divide Model has led to the expansion of federal power when states have sought to address municipal insolvency outside of bankruptcy, this section examines how this model has likewise expanded federal power inside of bankruptcy. Since the municipal bankruptcy law's first enactment, there has been a persistent concern that bankruptcy courts might overreach into areas of state control. ${ }^{207}$ The municipal bankruptcy laws have always contained provisions aiming to

${ }^{203} I d$. at 1942.

${ }^{204} \mathrm{Id}$. at 1949 (Sotomayor, J., dissenting) ("The structure of the Code and the language and purpose of $\S 903$ demonstrate that Puerto Rico's municipal debt restructuring law should not be read to be prohibited by Chapter 9.").

${ }^{205}$ See id. at 1945.

${ }^{206}$ See Puerto Rico v. Sanchez Valle, 136 S. Ct. 1863, 1868 (2016) (describing Puerto Rico's "unique political relationship" with the United States).

${ }^{207}$ See supra Part I.A-I.C. 
limit courts' reach to only the business, or private, activities of municipalities, leaving governance matters in the hands of the state. ${ }^{208}$

This debt-governance divide has raised important questions about the effectiveness and limits of the municipal bankruptcy laws. How far can bankruptcy law reach into the operational restructuring of a municipal debtor? And how much room, if any, is there for state law to exercise its operational control to influence the financial restructuring of municipalities in bankruptcy? The first question is a longstanding one, identified in McConnell and Picker's seminal work in this field; however, it is one that has received renewed interest and importance in recent municipal bankruptcy cases. ${ }^{209}$ For example, as Melissa Jacoby has explored in great detail, bankruptcy courts may have much greater than anticipated power to influence operational matters through a combination of previously underappreciated procedural tools. ${ }^{210}$ The second question has likewise garnered more interest, as recent scholarship by Clayton Gillette and David Skeel has argued that bankruptcy courts should have more power to engage in operational restructuring. ${ }^{211}$

The cases below provide examples of how these issues have arisen and how courts recited the formal division between debt and governance while attempting at the same time to work within that formal divide in order to balance the federal and state interests in these disputes. Ultimately, as argued more fully in Part III infra, what these cases help show is that the formal distinctions between debt and governance and between federal and state control are simply not analytically useful. They fail both as descriptive and as prescriptive models of municipal bankruptcy federalism.

\section{Stockton, $C A$}

The bankruptcy of Stockton, California, brought to the fore the conflict between bankruptcy and state laws as related to pension obligations. ${ }^{212}$ As described in this subsection, the federal bankruptcy court addressed this issue within a Great Divide Model framework, treating bankruptcy law as having a monopoly on debt adjustment. The court's analysis reflects a more nuanced view of federalism; however, that view is largely obscured by the Great Divide Model formalism.

Stockton proposed a bankruptcy plan that would impair its bond obligations but leave intact its pension obligations. One bondholder, Franklin Templeton, objected to the plan confirmation, arguing in part that Stockton's refusal to impair its pension obligations showed that the plan was not

${ }^{208}$ See supra Part I.A-I.C.

${ }^{209}$ McConnell \& Picker, supra note 23.

${ }^{210}$ Jacoby, supra note 24.

211 Gillette \& Skeel, supra note 6.

${ }^{212}$ See In re City of Stockton, 526 B.R. 35 (Bankr. E.D. Cal.), aff'd in part, dismissed in part, 542 B.R. 261 (B.A.P. 9th Cir. 2015). 
proposed in good faith. ${ }^{213}$ To evaluate this argument, the bankruptcy court considered whether Stockton even could have impaired those obligations. At issue was whether California's pension laws would prohibit such impairment. Ultimately, the court held that even though Stockton could have impaired its pension plans, its refusal to do so was not in bad faith. ${ }^{214}$ The court's analysis of the interaction of California's pension laws with the federal bankruptcy laws was likely dicta, as the court would have upheld Stockton's plan whether or not bankruptcy law preempted California law. ${ }^{215}$ Nonetheless, the court's analysis of the matter is instructive.

At the heart of the dispute was California's Public Employees' Retirement Law (PERL). ${ }^{216}$ PERL purports to prohibit municipal debtors from rejecting any pension servicing contract between a bankrupt municipality and the California Public Employees' Retirement System (CALPERS). ${ }^{217}$

CALPERS contended that this California statute effectively prohibits Stockton from rejecting the pension servicing agreement, as such an agreement reflects an exercise of the state's "political or governmental" powers over Stockton. ${ }^{218}$ As a political or governmental power, CALPERS argued, bankruptcy law could not interfere with the California statute, as Section 903 preserves the state's control over the "political or governmental powers" of a municipal debtor. ${ }^{219}$

In considering this issue, the court began its analysis from a highly formalist position: "Congress has power, exclusive of the states, to legislate uniform laws on the subject of bankruptcy."220 Thus, the bankruptcy laws preempt California's attempt at protecting CALPERS plans. ${ }^{221}$ Otherwise,

213 See id.

${ }^{214}$ Id. at 62 " While the loss of about $\$ 30$ million is unfortunate for Franklin, it reflects the bargain that Franklin made and the risk that it undertook. Its $17.5 \%$ overall return is not so paltry or unfair as to undermine the legitimacy of classification in the plan or the good faith of the plan proponent.").

${ }^{215}$ See id. at 41 , n.6 (after suggesting that CALPERS lacked standing to oppose Franklin Templeton, the court dropped a footnote explaining that "[i]t is not necessary to explore CALPERS' motivations for its extraordinary legal effort in this case in defense of pensions for which it bears little financial risk. For whatever reason, CALPERS chose to intrude itself into this case and repeatedly (at virtually every hearing) insist that it is impossible as a matter of law to reject or modify its pension administration contract and the related pensions. This opinion answers the question that CALPERS kept thrusting upon the court.").

216 See, e.g., CAL. Gov'T CoDE $\$ 20460$.

${ }^{217}$ CaL. Gov't CoDE $\$ 20487$ ("Notwithstanding any other provision of law, no contracting agency or public agency that becomes the subject of a case under the bankruptcy provisions of Chapter 9 (commencing with Section 901) of Title 11 of the United States Code shall reject any contract or agreement between that agency and the [CALPERS] board pursuant to Section 365 of Title 11 of the United States Code or any similar provision of law; nor shall the agency, without the prior written consent of the board, assume or assign any contract or agreement between that agency and the board pursuant to Section 365 of Title 11 of the United States Code or any similar provision of law.").

${ }^{218}$ In re City of Stockton, California, 526 B.R. 35, 51-52 (Bankr. E.D. Cal.), aff'd in part, dismissed in part, 542 B.R. 261 (B.A.P. 9th Cir. 2015).

219 See id.

${ }^{220} \mathrm{Id}$. at $49-50$.

${ }^{221}$ See id. at 39. 
California law would "usurp the exclusive power of Congress to legislate uniform laws on the subject of bankruptcy."222

As to CALPERS' argument that Section 903 of the Bankruptcy Code saves certain state political and governmental legislation from the scope of preemption, the court held that the California statute did not fit within this exception. ${ }^{223}$ While Section 903 preserves state control over "political or governmental powers," it does not define what those powers include. Finding the legislative history opaque, the court looked to other provisions of Chapter 9 that require any bankruptcy plan to comply with state regulatory and electoral laws. The court determined that "political or governmental powers" should likewise be read as including regulatory approval requirements. ${ }^{224}$ This power excludes "financial and employment" relations. The court's conclusion bears quoting in full:

The 'political or governmental' functions in $\S 903$ refer to basic matters of the organization and operation of government that are incidents of sovereignty, but do not extend to financial relations between the state and its municipalities .... While $\S 903$ protects the basic incidents of state sovereignty-described as 'political and governmental' powers-from encroachment, contractual relations as between state and municipality are generally outside the ambit of 'political or governmental' powers. ${ }^{225}$

The court's analysis suggests that the contract between Stockton and CALPERS might qualify as political or governmental in nature if the facts were slightly different. California allows cities like Stockton to use private pension administrators instead of CALPERS. The pension laws provide certain incentives for cities to choose CALPERS—for example, CALPERS permits public employees to transfer their pension benefits if they transfer from one municipal employer to another-but they do not require cities to use CALPERS. ${ }^{226}$ CALPERS, in this sense, competes with private pension administrators. In this regime, to allow California law to elevate claims from CALPERS but not from private pension administrators would allow California to protect CALPERS' financial claims in the event of a municipal bankruptcy.

In contrast, if all California municipalities had to use CALPERS, then the protection of CALPERS in municipal bankruptcy could be interpreted as protecting the CALPERS pension administrative system more broadly. This would not be simply protecting CALPERS' financial interests in the event of a municipal bankruptcy, but it would also serve to protect the integrity of the public pension system. The court's analysis suggests that this distinction

\footnotetext{
$222 \mathrm{Id}$. at 57.

${ }^{223}$ See id. at 52.

224 See id. at 54.

${ }^{225} \mathrm{Id}$. at $54-55$.

${ }^{226}$ See id.
} 
might color the analysis of whether the California pension laws were "political or governmental" in nature.

\section{Detroit}

Detroit, like Pontiac just twenty miles away, was placed under the control of an emergency manager. Unlike Pontiac, though, the governor authorized the emergency manager to seek relief under Chapter 9 of the Bankruptcy Code. Bankruptcy law was perceived to be necessary, in part, to address the city's roughly $\$ 3.5$ billion unfunded pension obligations. ${ }^{227}$ The Michigan constitution protects such pension obligations as contractual in nature, meaning that state law efforts to reduce those obligations would be subject to challenge under the Contracts Clause. ${ }^{228}$ Bankruptcy law, then, presented the only legal tool to impose pension reductions.

One of the main issues in the case was whether the Michigan constitutional pension protections could in fact be overridden by the bankruptcy laws. As in Stockton's case, the Detroit court invoked the language of the Great Divide Model, making it appear that the interaction of federal and state law in this context is straightforward. But a closer look at the court's analysis reveals more complex competing concerns between federal supremacy and state sovereignty. The bankruptcy court held that the treatment of pension claims is governed by federal bankruptcy law, thus displacing the Michigan state constitutional protections for pension debt. ${ }^{229}$ While Michigan had the power to elect whether to invoke federal bankruptcy law, it did not have the power to change those bankruptcy laws:

Stated another way, state law cannot reorder the distributional priorities of the bankruptcy code. If the state consents to a municipal bankruptcy, it consents to the application of Chapter 9 of the bankruptcy code . . . A state cannot rely on the $\S 903$ reservation of state power to condition or to qualify, i.e., to 'cherry pick,' the application of the Bankruptcy Code provisions that apply in Chapter 9 cases after such a case has been filed. ${ }^{230}$

Federal law, according to the court, has an exclusive power over the adjustment of Detroit's debts.

Despite the court's adherence to the debt-governance paradigm, the court nonetheless found that state laws could guide the application of federal

${ }^{227}$ See In re City of Detroit, 504 B.R. 97, 113-14 (Bankr. E.D. Mich. 2013) (showing that this amount was subject to some dispute, with some groups arguing the figure was as low as one billion dollars).

${ }^{228} \mathrm{M}_{\mathrm{I}}$. ConsT. art. 9, $\$ 24$ ("The accrued financial benefits of each pension plan and retirement system of the state and its political subdivisions shall be a contractual obligation thereof which shall not be diminished or impaired thereby.").

${ }^{229}$ See City of Detroit, 504 B.R. at 150 ("Bekins makes it clear, however, that with state consent, the adjustment of municipal debts does not impermissibly intrude on state sovereignty.").

${ }^{230}$ Id. at 161. 
bankruptcy law. While bankruptcy law permitted Detroit to impair pension obligations despite the state constitutional protections, those pension protections were nonetheless relevant in determining the relative priority of the pension claims under the unfair discrimination test. Ultimately, through the plan of adjustment, the court permitted Detroit to favor pensioners over the objecting unsecured creditors, thereby effectively recognizing a de facto priority for pension obligations. ${ }^{231}$ In the end, pensioners received at least seventy percent of their claims, while many bondholders received less than ten percent. ${ }^{232}$ Even though both groups of creditors shared the same legal status as unsecured creditors and the plan discriminated in favor of pensioners, the court found that such discrimination was fair, based on the circumstances of the case-including the Michigan constitutional protection for pension obligations. ${ }^{233}$

Accordingly, despite the earlier ruling that Michigan state law could not re-order bankruptcy priorities, the court found that this constitutional protection was entitled to "substantial consideration and deference" in determining the relative treatment of pensioners to other classes of creditors holding legally similar claims against the city. ${ }^{234}$

This brief description of this one slice of Detroit's bankruptcy illustrates that federalism issues in municipal bankruptcy are not a zero-sum gamewhile bankruptcy law may override an absolute state pension protection law, state law remains relevant in shaping the treatment of pension holders. Matters that fall within the hybrid financial/governance region may be subject to both federal and state regulation.

\section{Summary}

These case studies reveal the dominance of the Great Divide Model in framing municipal bankruptcy issues; however, these cases illustrate the descriptive shortcomings of this model. The courts accepted the framework that debt adjustment matters fall within the exclusive domain of the federal bankruptcy laws. They used language that either explicitly or implicitly gave federal bankruptcy law a monopoly over debt-related matters. At the same time, though, the courts-particularly in Stockton and Detroit-recognized that debt adjustment matters may have important governance implications. Accordingly, state law may play an important role in debt adjustment matters.

\footnotetext{
${ }^{231}$ See In re City of Detroit, 524 B.R. 147, 272 (Bankr. E.D. Mich. 2014).

${ }^{232} \mathrm{See}$ id. at 180.

${ }^{233}$ See id. at 257.

${ }^{234} \mathrm{Id}$.
} 


\section{Failures of the Great Divide Model}

The previous parts have identified the sovereignty concerns underlying the debt-governance divide, explained how that divide is built into the statutory structure of the municipal bankruptcy laws, and illustrated how this debt-governance divide has been strained in the recent municipal insolvency crisis.

This part identifies the problems with the way the debt-governance divide has been applied. The formalistic approach reflected in much of the academic literature and cited in the recent municipal bankruptcy cases rests on a framework that envisions bankruptcy law as exclusively a federal power, overlooking the role of the state to regulate insolvency. Having drawn a line between the federal and state powers, this approach simply requires a court to place municipal restructuring matters in one of these two spheres. Political/governmental matters fit in the state sphere of power; financial matters fit in the federal. As the cases above highlight, however, many municipal obligations have elements of both-which courts have recognized but have struggled to operationalize.

This part critically examines both of these elements, first examining the notion of federal monopoly over bankruptcy and then the notion of separate debt and governance spheres. It then looks to the early Supreme Court cases of Ashton and Bekins and the federalism jurisprudence of that era as the source of this formalistic approach.

\section{A. Uniformity and Exclusivity}

Even though courts have often cited the general principle that Congress has the exclusive power to enact bankruptcy legislation, this is not precisely true. ${ }^{235}$ First, it overstates the significance of the Bankruptcy Clause. As discussed supra in Part I.A, despite the Bankruptcy Clause's use of the phrase "uniform laws on the subject of bankruptcies," this does not mean that the Constitution deprived states of their power to pass insolvency laws. ${ }^{236} \mathrm{Sec}-$ ond, even to the extent the federal bankruptcy laws preempt conflicting state laws under the Supremacy Clause, such a broad statement overstates the scope of "the subject of bankruptcies" for preemption purposes. While the Court has never struck down a bankruptcy law as outside the scope of the bankruptcy power, it has also left intact state insolvency laws except to the extent those laws would purport to discharge indebtedness. ${ }^{237}$ Thus, states

${ }^{2.35}$ See Lubben, supra note 140.

${ }^{236}$ See also discussion of Sturges v. Crowninshield, 17 U.S. 122 (1819) and its progeny, supra Part I.D.1.

${ }^{237}$ See Int'l Shoe Co. v. Pinkus, 278 U.S. 261, 265 (1929). 
continue to have debtor-creditor laws that function remarkably similar to federal bankruptcy law. ${ }^{238}$

Congress's bankruptcy power, then, can hardly be described as creating a uniform system for regulating debtor-creditor relations, and in the municipal bankruptcy context the claim to federal uniformity is even weaker. First, as described above, Congress cannot impose municipal bankruptcy laws on the states; rather, the states must opt in to the Chapter 9 system. ${ }^{239}$ Currently, only twenty-four states currently have opt-in legislation. ${ }^{240}$ Even in these states, the law places many conditions on this authorization. ${ }^{241}$ Thus, Chapter 9 has not created a uniform system of insolvency and-assuming some sort of state authorization is constitutionally mandated ${ }^{242}$-it is prohibited from doing so.

Second, even as to states that have opted in to the Chapter 9 system, there may be significant differences in outcomes, based on state-level treatment of property rights. ${ }^{243}$ This is true at some level in bankruptcy law generally-particularly as general bankruptcy law permits consumer debtors to look to state law in order to determine which assets it can shield from creditor collection. ${ }^{244}$ But, at least in that system, there is a uniform procedureall that "uniformity" constitutionally requires. ${ }^{245}$ That is, even though state exemption laws differ, the bankruptcy law is "uniform" in that it consistently looks to state law for all debtors no matter where located. ${ }^{246}$ In municipal bankruptcy, there is not even a uniform procedure for incorporating state law. Courts may look to state law in determining equitable priorities or in determining whether to otherwise honor state priority laws.

The uniformity arguments, therefore, greatly overstate the case. Congress's power is not exclusive, and the municipal bankruptcy laws do not create a uniform system for handling municipal insolvency - and, in fact,

${ }^{238}$ See Andrew B. Dawson, Better than Bankruptcy?, RuTG. L.J. (forthcoming 2017); Ronald Mann, An Empirical Investigation of Liquidation Choices of Failed High Tech Firms, 82 WASH. U. L.Q. 1375 (2004); Edward R. Morrison, Bargaining Around Bankruptcy: Small Business Workouts and State Law, 38 J. Legal Stud. 255, 257 (2009) (all discussing the use of state law "assignment for the benefit of creditors" proceedings as a bankruptcy alternative).

${ }^{239}$ See supra Part I.B.1.

${ }^{240}$ See Pew Charitable Trusts, supra note 7.

${ }^{241}$ See id.

${ }^{242}$ See Adam Feibelman, Involuntary Bankruptcy for American States, 7 DuKE J. CONST. L. \& PuB. PoL'Y 81, 108 (2012) (arguing that jurisprudential developments since Ashton and Bekins call into question whether state authorization is constitutionally required); see also Dmiszewicki, supra note 77.

${ }^{243}$ See Ponoroff, supra note 43, at 355 (" $[E]$ ver since the first long-standing federal bankruptcy law was enacted in 1898 , state law has continued to play a vital interstitial role in defining the commercial rights, interests and entitlements of participants in the bankruptcy case.").

${ }^{244}$ See id.

${ }^{245}$ See Hanover Nat. Bank v. Moyses, 186 U.S. 181, 189 (1902); Judith Schenck Koffler, The Bankruptcy Clause and Exemption Laws: A Reexamination of the Doctrine of Geographic Uniformity, 58 N.Y.U. L. REv. 22 (1983).

${ }^{246}$ See Koffler, supra note 245, at 45-46 (describing the "Moyses view that the constitutional stricture only requires a form of geographic uniformity that permits distinctions based upon state boundaries"). 
may be constitutionally prohibited from doing so, as states must choose to opt in to Chapter 9 bankruptcy relief.

\section{B. Debt-Governance Dichotomy}

The formalistic application of the Great Divide Model, after having identified the spheres of state and federal power, requires courts to place matters within one of those spheres. If a matter is political or governmental, then it belongs in the realm of state control; if it is financial, it belongs in the federal sphere.

As described above, though, there are many matters that have both political/governmental and financial elements. Any time a municipal debtor, for example, issues debt in order to fund public services, there would be a significant overlap between governance and finance matters. The most prominent example would be contractual obligations with municipal employees, as these contracts create financial obligations and enable the provision of public services. As the Detroit court recognized, the public pension obligations, while financial, have an important "mission-related" function. ${ }^{247}$

The Great Divide Model fails to provide an analytical framework for considering the role of federal and state law in resolving disputes in this hybrid debt-governance region. Even worse, this model works to obscure how courts actually analyze these matters. Its analytical framework calls for matters to be either in the federal or the state spheres, when in fact these spheres have significant overlap-and both federal and state law may apply in resolving such matters.

\section{Limiting Principles}

A final failure of the Great Divide Model is that it is highly susceptible to manipulation. The formalist approach relies on a bright-line distinction between debt and governance, and bright line tests may be easily sidestepped. Thus, a bankruptcy court might exercise considerable control over municipal governance under the guise of debt restructuring. As long as the court is operating in the realm of financial reorganization, there is little to push back against such federal intrusion.

As noted above, scholars have long noted that bankruptcy courts may be able to exercise significant indirect control over municipal governance. McConnell and Picker explored this issue in considering how a court could exercise "judicial control by a wink and a nod," as a court could refuse to confirm a plan unless, for example, the city promised to raise taxes. ${ }^{248}$ Gillette points out that courts may exercise control over not only how a city may exit bankruptcy but also on whether it may enter bankruptcy. For example, in determining whether the municipality is indeed "insolvent," the court 
has discretion to consider whether the city might in fact be able to pay its debts by first raising taxes. ${ }^{249}$

Melissa Jacoby's recent work analyzing the Detroit bankruptcy illustrates that the potential for federal control is even greater than previously appreciated. ${ }^{250}$ This begins with the unique judicial selection process in Chapter 9, in which the chief judge of the circuit court of appeals is empowered to appoint the Chapter 9 judge-a process that, she argues, "offers an opportunity for the bankruptcy, district, and circuit courts to discuss a philosophy for, and collaborate on, management of the case."251 The court's ability to then manage the case through confidential mediation, to enlist experts and create teams to assist with the court's duties, and to involve Detroit residents in the decision-making process all expanded the court's powers beyond the traditional account - and beyond the formalist structure of the debtgovernance divide. ${ }^{252}$ This expansion leads Jacoby to conclude that the statutory restraints on judicial interference with local governance are ineffective: even though the Detroit court actually may have been "literally consistent" with the statutory restraints, she argues that these statutory restraints "are not nearly as robust as is often claimed."253

Whereas Jacoby's analysis of the Detroit Blueprint sees "wink and a nod" judicial interference as inconsistent with the structure of Chapter 9 and potentially problematic from a federalism perspective, Gillette and Skeel view this as an opening for even more federal intervention. ${ }^{254}$ If courts can indirectly require municipal debtors to raise taxes, they suggest that courts could be authorized to do so directly. That is, if the statutory structure invites indirect interference, the non-interference principle must not be constitutionally mandated. It reflects, instead, a policy preference-a preference that, they argue, prevents bankruptcy from "fixing" bankrupt municipalities. ${ }^{255}$

Gillette and Skeel's argument reflects the concern that without a strong bankruptcy power states may lack the incentive or the practical ability to truly rehabilitate cities. ${ }^{256}$ Governance reform may involve unpopular politi-

${ }^{249}$ Gillette, Fiscal Federalism, supra note 13, at 293 (citing as an example the eligibility determination of Bridgeport, Connecticut).

${ }^{250}$ Jacoby, supra note 24.

251 Id. at 73.

252 See id. at 99.

${ }^{253}$ Id. at $104-05$.

${ }^{254}$ Compare Jacoby, supra note 24, at 105 ("I have uncovered no evidence that Congress adopted this language with a wink or nod to courts that they should exercise control through other means."), with Gillette \& Skeel, supra note 6, at 1200 (noting that their proposal for bankruptcy oversight of operational restructuring "is less radical than it initially appears," because, in part, "it is commonly recognized that bankruptcy courts have the capacity to do indirectly what they cannot do directly by refusing to confirm plans that do not include details such as tax increases that the municipality might otherwise reject").

${ }^{255}$ Gillette \& Skeel, supra note 6, at 1165-66 (noting that Chapter 9 reflects "congressional concern with constitutional limitations on federal diminution of state sovereignty in Chapter 9 proceedings" but that such diminution would not actually "run afoul of constitutional principles").

${ }^{256}$ Id. at 1155 ("We share McConnell and Picker's intuition that relief for fiscally distressed municipalities necessarily requires more than debt reduction."). 
cal decisions, effectively deterring city leaders from enacting reforms that would benefit the city in the long term without any benefit to the leaders. ${ }^{257}$ They cite as an example the ability of the District of Columbia Financial Control Board to make politically necessary but unpopular reforms. ${ }^{258}$ Former Washington, D.C. mayor Marion Barry, for example, noted that the federally appointed financial control board was able to take reform measures that he politically would have been unable to do. ${ }^{259}$ Even when reforms are politically palatable, they may not be attainable due to municipalities' fragmented decision-making structure. ${ }^{260}$ Such a structure may invite fiscal policies that benefit some of the decision makers but that deplete the municipal fisc-effectively creating a tragedy of the commons situation. ${ }^{261}$ Unless there is a strong third party with the authority to restructure the city's governance, Gillette and Skeel argue that internal politics is unlikely to fix such problems.

Gillette and Skeel urge that a bankruptcy court can and should be that third party. ${ }^{262}$ Giving this power to a bankruptcy court can solve the problems of fragmented decision-making structures. ${ }^{263}$ And it can solve the problem of politically unpopular reforms, as a strong bankruptcy power may permit states to offload these decisions on to the court. ${ }^{264}$

Gillette and Skeel's work, along with that of others, takes important steps in the right direction towards developing an alternative model to understanding the tension between state sovereignty and the federal bankruptcy power. Any alternative model, though, must provide some means to define the contours of the federal power. For example, as discussed in the following part, Gillette and Skeel would give more power to bankruptcy courts to shape governance reform, but they recognize that there may be constitutional limitations to that power. Their work, while an insightful critique of the notion that the Great Divide Model is constitutionally mandated, does not give us a systematic theoretical framework within which to evaluate those limits. The same is true in considering the implications of the indirect control Jacoby has identified in the Detroit Blueprint.

\section{Beyond the Great Divide}

As described in the prior part, the formalist Great Divide Model fails both descriptively and prescriptively. It obscures the judicial decision-making process behind formal labels of "debt" and "governance," and it

${ }^{257}$ See id. at $1195-96$.

${ }^{258}$ Id. at $1196 \mathrm{n.211.}$

${ }^{259}$ See id.

${ }^{260}$ See id. at 1184 ("The most common governance problem . . . is a fragmented local decision-making structure.").

${ }^{261}$ See id. at 1185.

${ }^{262} \mathrm{Id}$.

${ }^{263} \mathrm{Id}$.

${ }^{264} \mathrm{Id}$. 
provides little guidance for analyzing federalism issues in municipal insolvency. While this paradigm may provide a useful heuristic for understanding the basic structure of municipal bankruptcy laws, it fails to provide a structure to analyze the role of both the federal and state governments in this sphere. Further, the Great Divide Model fails to connect with modern federalism jurisprudence, from which it could draw important principles as to the key question of the limits of federal control.

The Great Divide Model is rooted in the Tenth Amendment jurisprudence of the Ashton era, analyzing federalism questions as one of allocation: the municipal bankruptcy power must either belong in the federal sphere or the state sphere. ${ }^{265}$ This model has been described as one of "dual federalism." 266 The Court began moving away from dual federalism at the same time as it upheld the revised municipal bankruptcy laws in Bekins. ${ }^{267}$

Even though the Court's federalism jurisprudence has largely moved away from the highly formalistic dual federalism model, discussions of municipal bankruptcy federalism remain rooted in the allocative, formalist Great Divide Model. In some sense, this is not unique to municipal bankruptcy, as others have lamented that the dual federalism model continues to "haunt" modern federalism jurisprudence. ${ }^{268}$ In municipal bankruptcy, this adherence to an old model of federalism may reflect, in part, the dearth of municipal bankruptcy cases. Such cases have historically been rare and, until recently, have involved public utilities more often than cities or counties. ${ }^{269}$ Thus, the Court has not revisited these federalism issues in a constitutional context since Faitoute in 1946. ${ }^{270}$

This adherence to a dual federalist-type model in municipal bankruptcy may also reflect the lack of a theory of bankruptcy federalism more broadly. Since Bekins, the bankruptcy power has grown significantly, and the Court has not provided any serious limitation on that power. ${ }^{271}$ Instead, it has

${ }^{265}$ Emest Young, Federalism as a Constitutional Principle, 83 U. CIN. L. REv. 1057, 1065 (2015) [hereinafter Young, Federalism] ("Enumerated powers gave rise to a model of federalism doctrine called 'dual federalism,' and it worked well enough for the first century and a half of our history. The grant of certain powers to the national government and the reservation of the rest to the States created two separate and exclusive spheres of regulatory jurisdiction.").

${ }^{266}$ Id.

${ }^{267}$ See id. at 1067 (noting that "the constitutional model of dual federalism died out around 1937, a casualty of the Supreme Court's 'switch in time' that staved off FDR's court packing plan by ending the Court's resistance to the New Deal.").

${ }^{268}$ See Roderick M. Hills, Jr., The Political Economy of Cooperative Federalism: Why State Autonomy Makes Sense and "Dual Sovereignty" Doesn't, $96 \mathrm{MICH}$. L. Rev. 813, 818 (1998) ("The problem is that the Court's jurisprudence is still haunted by a theory of state autonomy it inherited from nineteenth-century jurisprudence-a theory that I call nationalistic dual federalism.").

${ }^{269}$ See Gillette \& Skeel, supra note 6, at 1183 (noting scarcity of bankruptcies involving substantial cities).

${ }^{270}$ See generally Faitoute Iron \& Steel Co. v. City of Asbury Park, 316 U.S. 502 (1942).

271 See KLEE, supra at note 73, at 126-29 ("[T] he Court has refused to define the outer limits of the 'subject of bankruptcies." "). 
defined the core of the bankruptcy power extremely broadly as dealing with the "restructuring of debtor-creditor relations." 272 Scholars have attempted to draw limits to the bankruptcy power, but overall the conclusion has generally been that bankruptcy is just different. ${ }^{273}$

The Great Divide Model both reflects and reinforces this notion of bankruptcy exceptionalism. To the extent this formalism is justifiable, it is because bankruptcy federalism must be different. The Great Divide Model's formalism perpetuates this notion of exceptionalism because it isolates bankruptcy federalism questions from broader principles of federalism. In this sense, the Great Divide Model's formalism obscures the constitutional issues in municipal bankruptcy and these issues from the broader federalism jurisprudential principles needed to analyze them. This creates significant problems in evaluating the difficult issues that have arisen in Detroit, Stockton, and other municipal bankruptcies. It also fails to create a framework to analyze proposals, such as that of Gillette and Skeel, to expand the powers of judges in municipal bankruptcy. 274

This part of the article argues that municipal bankruptcy federalism is better understood under a functional model-one that considers the function of the municipal bankruptcy laws and that of the state laws with which it interacts. This approach recognizes that municipal bankruptcy will necessarily interfere with the contractual relationships of a bankrupt municipality with its creditors, and that interference may have consequences for the municipality's ability to provide services. However, that interference is limited to the goal of restructuring the municipality's finances. If the state consents to federal bankruptcy interference, the municipal bankruptcy laws may displace state laws in this process, but that displacement is not absolute. States retain the power to control governance matters, subject of course to federal bankruptcy supremacy. This functional model is consistent with the Court's jurisprudential shift from Ashton (rejecting the first municipal bankruptcy law) to Bekins (upholding the revised municipal bankruptcy law). It is consistent with the way the courts in Stockton and Detroit ultimately analyzed the interaction of bankruptcy law with state pension protection laws. And it

${ }^{272}$ Stern v. Marshall, 574 U.S. 462, 475 (2011) (quoting N. Pipeline Const. Co. v. Marathon Pipe Line Co., 458 U.S. 50, 80 n.31 (1982)) ("From the beginning, the 'core' of federal bankruptcy proceedings has been 'the restructuring of debtor-creditor relations." ").

${ }^{273}$ See Daniel Austin, The Bankruptcy Clause and the Eleventh Amendments: An Uncertain Boundary Between Federalism and State Sovereignty, 42 U.S.F. L. REv. 383 (2007); Ralph Brubaker, Explaining Katz's New Bankruptcy Exception to State Sovereign Immunity: The Bankruptcy Power as a Federal Forum Power, 15 Am. Bankr. InST. L. Rev. 95 (2007); Jonathan C. Lipson, Debt and Democracy: Towards a Constitutional Theory of Bankruptcy, 83 Notre Dame L. Rev. 605 (2008); Thomas E. Plank, Bankruptcy and Federalism, 71 Fordham L. Rev. 1063 (2002); James Steven Rogers, The Impairment of Secured Creditors' Rights in Reorganization: A Study of the Relationship between the Fifth Amendment and the Bankruptcy Clause, 96 HARv. L. REv. 973-1031 (1983) (challenging the accepted proposition of reorganization law that the Fifth Amendment limits "the extent to which secured creditors may be subjected to the risk of loss due to restraint of their foreclosure rights").

${ }^{274}$ See Gillette \& Skeel, supra note 6. 
is consistent with how the Court's federalism jurisprudence has moved away from dual federalism's allocative model. Understanding municipal bankruptcy federalism in a functional manner provides a framework for identifying the issues of federal control in municipal bankruptcy. And connecting municipal bankruptcy federalism with broader principles of federalism helps to provide the tools to analyze these issues. In particular, it provides a way for considering the "Detroit Blueprint" for courts to indirectly control local governance and for the proposal by Gillette and Skeel to permit courts to exercise more direct control over local governance. Finally, this part concludes by considering how this framework underscores the need to read the Court's recent Puerto Rico case narrowly.

\section{A. Functional Analysis of Municipal Bankruptcy Federalism}

This section argues that a functional model of municipal bankruptcy federalism comports with the Court's decision in Bekins. It better describes the way courts have analyzed the interaction of federal and state laws in the context of public pension debt. And it provides a more workable framework for courts to consider the intersection of federal bankruptcy and state laws.

\section{Re-Examining Ashton and Bekins}

Reviewing Ashton ${ }^{275}$ (in which the Court struck down the first municipal bankruptcy law) and Bekins ${ }^{276}$ (in which the Court upheld the revised municipal bankruptcy law), one can observe a jurisprudential shift, however slight, from a formalistic model to a more functionalist model. This shift, more than any particular changes in the revisions made to the original 1934 Act, helps explain the Court's decision upholding the revised 1937 Act in Bekins. ${ }^{277}$ This shift provides the initial support for the functionalist approach advocated in this article.

Whereas Ashton focused on the dual federalism model in which the states have non-delegable control over their own municipalities, in Bekins the Court moved away from this model, instead focusing on the federal-state cooperative framework for resolving municipal distress. Ashton found municipal bankruptcy law to be unconstitutional because bankruptcy would necessarily invite some federal intrusion into municipal governance, which would unconstitutionally surrender state sovereignty and expand the powers of Congress. ${ }^{278}$ Bekins, in contrast, embraced this notion of the state inviting

275298 U.S. 513 (2012).

276304 U.S. 27 (2012).

277 See Gillette \& Skeel, supra note 6.

${ }^{278}$ Ashton v. Cameron Cty. Water Improvement Dist., 298 U.S. 513, 531 (1936) ("Neither consent nor submission by the states can enlarge the powers of Congress; none can exist except those which are granted. The sovereignty of the state essential to its proper functioning under the Federal Constitution cannot be surrendered; it cannot be taken away by any form of legislation.") (citations omitted). 
(limited) federal intrusion: "Nor did the formation of an indestructible Union of indestructible States make impossible cooperation between the Nation and the States through the exercise of the power of each to the advantage of the people who are citizens of both." 279

This is not to say the Court rejected the basic premise that states have the right to control their municipalities and Congress has the right to pass federal bankruptcy laws. Indeed, the Court recognized the issue of state control over municipalities as inherent in state sovereignty. But, the Court recognized that state sovereignty did not preclude states from inviting a federalstate solution to municipal insolvency. That is, the question of whether federal law can restructure municipal debt is not whether that power falls within the federal sphere of power or that of the states; rather, it is a question of whether the Constitution permits a shared sphere wherein the federal and state governments can work together to create a solution to municipal insolvency. The Court answered this question in the affirmative because it found the power to enhance the state's control over its municipalities.

\section{Federal-State Law Interaction in Chapter 9: Pension Obligations}

Consistent with the Bekins description of municipal bankruptcy law as a cooperative effort between the federal and state governments, a functional model of municipal bankruptcy law permits courts to view federalism issues in this context as something more than an all-or-nothing, federal-or-state law decision. The interaction of federal and state law in this context is not a zerosum game, wherein either federal or state law applies; rather, both federal and state law may work together in resolving municipal distress.

This subsection re-examines the courts' treatment of pension obligations in Detroit and Stockton as an illustration of this functional approach. As seen in those cases, the treatment of pension obligations-which, as discussed supra have both financial and governance elements-was not wholly governed by federal or state law; rather, both federal and state law worked in tandem in determining the rights of pensioners. It then considers how this functional approach can provide a framework for considering the limits of federal interference in municipal governance, as illustrated in Jacoby's "Detroit Blueprint" and as advocated by Gillette and Skeel's proposal for greater federal control in this context.

Although the courts in Detroit and Stockton both proclaimed a formalistic analysis when faced with the question of whether a city can restructure pension debts despite state law protections, the courts' analyses are better understood as applying a functional approach. The pension question in both Detroit and Stockton was whether bankruptcy law overrides state pension protections. Under the Great Divide Model, the problem would be framed as one of allocation: bankruptcy law governs debt adjustment and debt adjustment includes creditor distributions, bankruptcy law therefore providing the

${ }^{279}$ Bekins, 304 U.S. at 53. 
exclusive rule for creditor distributions. Under a functional approach, the question does not require an all or nothing answer. State pension protection laws may survive preemption, in whole or in part, in accordance with their function as financial or political in nature.

Both the Detroit and Stockton courts framed the issue within the Great Divide Model; however, their analysis of the issue is better understood through a functional lens. In Detroit, despite the court's statements that bankruptcy law overrides Michigan's constitutional protection for pension obligations, the court ultimately approved a plan that paid significantly more to pensioners than to general unsecured creditors, even though the claims of both groups shared legal priority. ${ }^{280}$ The court's reasoning relied on the governmental function of the pension obligations: the City's mission is to provide public services; employees and retirees are essential to perform those services; pension obligations are a core platform of the City's relationship with those employees and retirees; therefore, the treatment of pension obligations is governmental in nature. ${ }^{281}$ At the same time, though, the court still permitted some modifications to the pension obligations, recognizing that these were financial in nature as well. In fact, the court suggests the City's plan. would have failed the feasibility test but for those pension modifications. ${ }^{282}$

The Stockton court likewise framed the issue in a very formalistic way, first ascribing exclusive power to the federal government to address municipal insolvency, then concluding that the bankruptcy laws preempt the California pension protection laws. ${ }^{283}$ But the court then turned to a more functional analysis of some of those pension protection laws, particularly whether the state law prohibited the use of bankruptcy to reject pension servicing agreements with CALPERS. ${ }^{284}$ The court considered whether those protections were financial or operational. The laws could conceivably be operational if they were designed to protect the integrity of the California state pension system. ${ }^{285}$ That might have been the case if California required all municipalities to use CALPERS for pension servicing. But, as the court noted, California permits municipalities to use private pension servicers. The court concluded that CALPERS was competing in a private market and acting as a private enterprise. Any protection for CALPERS reflected a state law decision related to public finance, not public services. In that way, the state law pension protection was effectively as if the State had sought to

${ }^{280}$ See In re City of Detroit, 524 B.R. 147 (Bankr. E.D. Mich. 2014). Although the primary fight in Detroit was between pensioners and bondholders, the city ultimately settled the bondholder claims, leaving only the general unsecured claims and those in the "convenience" class of creditors, defined as those unsecured claims of $\$ 25,000$ or less.

281 See id.

${ }^{282}$ See id. at 231 (quoting from the court's feasibility expert, Martha Kopacz, whose report noted that "[t]he City must be continually mindful that a root cause of the financial troubles it now experiences is the failure to properly address future pension obligations").

${ }_{283}$ See In re City of Stockton, 526 B.R. 35, 62 (Bankr. E.D. Cal.), aff'd in part, dismissed in part, 542 B.R. 261 (B.A.P. 9th Cir. 2015).

284 See id. at 61 .

${ }^{2}{ }^{45}$ See id. 
allow municipalities to file bankruptcy but not to impair obligations owed to the state. ${ }^{286}$

When viewing the question of pension protections through this functional lens, it is possible to balance the federal bankruptcy power with the states' governance/political function, thus maintaining the federalism balance upheld in Bekins. Such an approach is necessarily fact-intensive. It requires examining the function of Michigan's constitutional pension protections and of California's public pension laws. A court would need to look at the origins of those protections and the role these protections play in the State's human resource management, as well as the Municipality's anticipated ability to fulfill its pension obligations. For example, the court might consider whether the pension protection was newly enacted, whether municipal employees are covered by the Social Security Act, and whether the pension obligations were reasonable in structure.

Ultimately, the functional analysis still requires evaluating state laws as serving both governmental and financial purpose. However, it recognizes that laws may serve both purposes. The functional approach leaves room for such hybrid laws to influence bankruptcy outcomes-these laws are neither excluded from preemption nor entirely displaced by federal law; rather, they may work alongside federal law. The state law pension protections may not override bankruptcy law, but at the same time they may be able to work alongside federal bankruptcy law in order to protect the state's sovereignty interests.

Accordingly, a functional approach recognizes that municipal bankruptcy federalism is not a zero-sum game where federal law preempts state laws or does not. Indeed, the rejection of a zero-sum approach is implicit in Bekins. That case emphasized that state consent legitimizes a federal role in the governance of municipal insolvency because that federal role works not to diminish states' control over their own municipalities but to bolster it. Underlying the court's approach to Michigan's pension protection laws was the fact that Michigan's consent legitimized some federal intrusion into governance matters, but such consent did not render irrelevant state law priorities. Rather, state priorities that are plausibly vital to governance matters may play a significant role. At the same time, as recognized in Stockton, not all state laws have such a governance function. State laws that serve, for example, to insulate state debts from a bankruptcy discharge may serve a principally financial motive. There is a role for the bankruptcy court to determine whether state laws play a vital governance role or whether accommodating state law would inflict unacceptable costs to federal bankruptcy policy.

This approach-which looks to the compatibility of federal and state interests_-distinguishes municipal-bankruptcy federalism from the Court's

${ }^{286}$ See id. at 57 ("[S]pecial insulation of a state actor in a municipal insolvency is contrary to chapter 9 precedent.") (citing Mission Indep. Sch. Dist. v. Texas, 116 F.2d 175, 178 (5th Cir. 1940)). 
analysis of federalism under the Tax Clause as it relates to intergovernmental immunity and the Commerce Clause as it relates to areas of exclusive state power. When examining the limits of federal power in those doctrinal areas, the Court has expressed uneasiness with tests based on whether the federal power would intrude upon traditional governmental functions of the state. ${ }^{287}$ The difficulty of drawing constitutional distinctions between a state's traditional governmental functions and its nontraditional proprietary functions in setting limits to federal authority inevitably puts the courts in the position of picking and choosing among state governance priorities-a role that is profoundly inconsistent with federalism. ${ }^{288}$

The blurriness of the distinctions may be as notable in the bankruptcy context as in the context of intergovernmental tax immunity or Commerce Clause doctrine. But that matters far less in the municipal bankruptcy context. For one thing, the distinction between a municipality's private and public functions is congressionally sanctioned: it is built into the statutory structure of Chapter 9 of the Bankruptcy Code. Moreover, taking Bekins's insight to heart, the distinction is state-sanctioned in any case that comes before the court. And finally, to a degree that is not always present in these other federalism contexts, the judicial outcome need not be binary; rather, there is room for both state and federal law to work together.

\section{Federal-State Law Interaction: Federal Intrusion}

This functional approach also helps to highlight the federalism concerns identified in Melissa Jacoby's analysis of judicial control in the Detroit Bankruptcy_-what she terms the "Detroit Blueprint," whereby courts may indirectly assert control over municipal governance. ${ }^{289}$ Not only can bankruptcy courts indirectly control bankrupt municipalities through the plan confirmation requirements, as noted first by McConnell and Picker, but they can assert control over municipalities through a myriad of procedural and "below the radar" tactics. ${ }^{290}$

Jacoby's analysis on this dynamic is primarily descriptive; however, she voices skepticism that this "wink and a nod" control is consistent with Chapter 9 of the Bankruptcy Code. ${ }^{291}$ Sections 903 and 904 attempt to define the limits of federal control in Chapter 9 , first by reserving powers to the

${ }^{287}$ See, e.g., New York v. United States, 326 U.S. 572, 583-84 (1946) (describing as "untenable" an intergovernmental tax immunity doctrine "derived from such untenable criteria as 'proprietary' against 'governmental' activities of the States, or historically sanctioned activities of Government or activities conducted merely for profit"); see also discussion of Nat'l League of Cities v. Usery and Garcia v. San Antonio Metro. Transit Auth, infra notes 304-10.

${ }^{288}$ See discussion of Nat'l League of Cities v. Usery and Garcia v. San Antonio Metropolitan Transit Authority, infra notes 304-10.

${ }_{289}$ Jacoby, supra note 24.

${ }^{290} \mathrm{Id}$.

${ }^{291}$ Id. at 105 ("I have uncovered no evidence that Congress adopted this language with a wink or nod to courts that they should exercise control through other means .... Whatever benefits might flow from a more experimental system, the history of section 904 does not 
states and then by limiting the power of the bankruptcy court. ${ }^{292}$ Since Congress created statutory safeguards to prohibit direct interference, is it really safe to assume that Congress intended to permit indirect interference?

The problem she identifies is easily swept under the rug under a formalist system: the court did not directly contravene the statutory prohibitions. Therefore, there is no need for concern. As long as the court is operating within the federal sphere of debt restructuring, there is no problem. Or, as long as the court is exercising its case management discretion, there is likewise no concern with federal intrusion in state sovereignty. Such a categorical approach avoids confronting the important and challenging question of how far a federal court may reach without upsetting the constitutional balance of the municipal bankruptcy laws.

When municipal-bankruptcy federalism is understood as operating to support state sovereignty while respecting federal supremacy, we can no longer treat bankruptcy court control over governance matters-either under the guise of debt restructuring or case management-as an anomaly to be swept under the rug or an error to be definitively rejected. Municipal bankruptcy law has long been concerned with preserving state control over municipal governance and operational restructuring. It has purposely been narrowly tailored to remain flexible enough to be a useful tool for states to address municipal insolvency. At the same time, though, beginning with Congress's response to Faitoute, such flexibility operates within the constraints of federal primacy-which Congress has asserted through its efforts to create a uniform system for resolving municipal insolvency.

In short, faced with increasing bankruptcy courts' authority over operational restructuring, the Great Divide Model invites either an overreaction (no federal intrusion at all is permissible) or an under-reaction (federal intrusion is fine, so long as it is under the guise of financial restructuring). In contrast, a functionalist approach recognizes that such a shift towards greater court authority is indeed a dramatic one, but one worth careful consideration. An aggrandized federal role may pose problems, but it also offers the potential for a constructive, cooperative federal-state solution to municipal insolvency.

\section{B. Federalism Limitations on Bankruptcy Court Interference}

A functional lens not only helps to highlight how federal bankruptcy court interference is inconsistent with Chapter 9's history and structure, but it also helps to connect municipal bankruptcy federalism with broader principles of federalism jurisprudence. Modern federalism jurisprudence moves beyond a formalist categorical exercise, presenting instead a more nuanced understanding of federal-state interaction in various regulatory arenas. This

suggest that Congress intended to create such a laboratory, particularly one that does not contain a mechanism for systematic evaluation.").

29211 U.S.C. $\S \S 903,904$ (2012). 
section is not intended as an exhaustive discussion of the Court's federalism jurisprudence, nor is it intended to demystify bankruptcy exceptionalism. Instead, this section has the more modest goal of considering how federalism doctrine may help frame the issues of municipal bankruptcy federalism.

The Great Divide Model's allocation of powers to either the federal or the state sphere reflects the "dual federalism" model of federalism embraced by the Court prior to the New Deal "switch in time." 293 "Dual federalism" sought to allocate powers as belonging either to the federal or the state governments, with a sense that some powers were "local" and others "national." 294 This model of federalism was premised on a state of the world in which courts could draw a line between these different spheres-an exercise that became increasingly difficult as these spheres overlapped. ${ }^{295}$ The role of courts in this model was to determine whether a power in question belonged in one sphere or the other. ${ }^{296}$

As noted by scholars in this field, this dual federalism model failed to capture federal-state interaction in regulatory regimes. ${ }^{297}$ Not only does it fail descriptively to capture federal-state relations in many regulatory areas, but it also fails prescriptively in that it provides little useful guidance for measuring when federal regulation has intruded too much into state sovereignty. ${ }^{298}$ Finally, as argued by cooperative federalism scholars, traditional notions of federalism are simply inapt when evaluating the myriad federal regulatory programs that do not displace states from the regulatory sphere but instead employ states within federal regulatory programs. ${ }^{299}$ Many federal regulatory programs-e.g., environmental, energy, election, and telecommunications regulations-involve cooperative frameworks that are best understood not under a model of dual sovereigns but of master-servant. ${ }^{300}$

The "last gasp" of dual federalism ${ }^{301}$ was articulated in National League of Cities $v$. Usery, a case examining the application of amendments

${ }^{293}$ See Edward S. Corwin, The Passing of Dual Federalism, 36 VA. L. Rev. 1, 17 (1950); Neil S. Siegel, Commandeering and Its Alternatives: A Federal Principle, 59 VAND. L. Rev. 1629, 1636 (2006); Young, Federalism, supra note 265, at 1067 (noting that "the constitutional model of dual federalism died out around 1937, a casualty of the Supreme Court's 'switch in time' that staved off FDR's court packing plan by ending the Court's resistance to the New Deal").

${ }^{294}$ See Young, Federalism, supra note 265, at 1065.

${ }^{295}$ See id.

${ }^{296}$ See id.

${ }^{297}$ See, e.g., Philip J. Weiser, Federal Common Law, Cooperative Federalism, and the Enforcement of the Telecom Act, 76 N.Y.U. L. REv. 1692, 1693 (noting the tension between cooperative regulatory programs and the "dual federalism" model, using the Telecom Act as an example).

${ }^{298}$ See Heather K. Gerken, Foreword: Federalism All the Way Down, 124 Harv. L. Rev. $4,13(2010)$.

${ }^{299} \mathrm{Id}$.

${ }^{300}$ See, e.g., Felix Mormann, Clean Energy Federalism, 67 Fla. L. Rev. 1621 (2015) (energy law federalism); Justin Weinstein-Tull, Election Law Federalism, 114 Mich. L. Rev. 747 (2016); Weiser, supra note 297 (cooperative federalism in telecommunications).

${ }^{301}$ See Ernest A. Young, Dual Federalism, Concurrent Jurisdiction, and the Foreign Affairs Exception, 69 Geo. WASH. L. Rev. 139, 149 (2001) (describing the decision as having "the feel of a 'last gasp' for dual federalism even before it was overruled"); see also Charlton 
to the Fair Labor Standard Act that would extend that act's minimum wage and maximum hour requirements to state employment agreements. ${ }^{302}$ The Court reasoned that to interfere with state employment agreements would be to interfere with states' and local governments' ability to provide traditional public services. ${ }^{303}$ As such, it held that "insofar as the challenged amendments operate to directly displace the States' freedom to structure integral operations in areas of traditional governmental functions, they are not within the authority granted Congress by Art. $1, \S 8, \mathrm{cl} .3 .{ }^{\prime 304}$

This "traditional governmental functions" test has been mostly rejected; however, the principle behind that test has persisted: traditional governmental functions are integral to the notion of state sovereignty. The Court formally rejected National League of Cities' traditional governmental functions test in Garcia v. San Antonio Metropolitan Transit Authority in 1985, lamenting that "the attempt to draw the boundaries of state regulatory immunity in terms of 'traditional governmental function' is not only unworkable but is also inconsistent with established principles of federalism." 305 Without an organizing principle to categorize state powers as traditional/non-traditional governmental functions, National League of Cities' dual federalism model was simply unworkable. It put unelected federal judges in the position of determining which state services were sufficiently vital or traditional to deserve protection from federal interference, and which were not. ${ }^{306}$ As the Court noted, such a system would invite "unelected federal judiciary to make decisions about which state policies it favors and which ones it dislikes." 307

In contrast, Garcia favored a judicial approach that relied instead on the "procedural safeguards inherent in the structure of the federal system," rather "than by judicially created limitations on federal power." 308 States could protect themselves against federal intrusion through the political process-that is, through their representative role in the federal government. Thus, the role of the courts was not to draw lines between spheres of power but to ensure faithfulness to constitutional political safeguards. ${ }^{309}$

Although Garcia rejected the traditional/non-traditional governmental function test for limiting federal power, this distinction has retained some

C. Copeland, Federal Law in State Court: Judicial Federalism Through a Relational Lens, 19 WM. \& MARY B. RTS. J. 511, 529 (2011).

${ }^{302} 426$ U.S. 833, 852 (1976).

${ }^{303}$ See id.

${ }^{304}$ Id. (emphasis added).

${ }^{305} 469$ U.S. 528, 531 (1985).

${ }^{306}$ See id. at 546.

${ }^{307}$ Id.

${ }^{308} \mathrm{Id}$. at 552.

${ }^{309}$ See Andrzej Rapaczynksi, From Sovereignty to Process: The Jurisprudence of Federalism after Garcia, 1985 SuP. CT. Rev. 341 (1985) ("All that Garcia, on its face, requires is that a justification of any federalism-related limitation on the national government be one of 'process' (rather than relying on the alleged existence of some 'sacred province of state autonomy') and that the process failure, required for judicial intervention, be on the national level.") (quotations and citation omitted). 
vitality under the "clear statement rule." 310 In Gregory v. Ashcroft, the Court held that Congress cannot intrude upon "state governmental functions" without a clear statement of its intent to do so."11 In that case, the Court considered whether a Missouri mandatory retirement law for state judges violated the federal Age Discrimination in Employment Act of 1967. Justice O'Connor noted that, when Congress's intent to preempt is unclear, there is a presumption that Congress did not intend to preempt state laws "in areas traditionally regulated by the States." 312

The Court also crafted another sovereignty-based limitation on Congress's powers that prohibits Congress from commandeering state governments. ${ }^{313}$ In New York $v$. United States, the Court held that, even though Congress has the power to regulate the disposal of radioactive waste-even entirely displacing states from the field through preemption if it so chooses-Congress may not force states to legislate along lines dictated by federal regulations. ${ }^{314}$ One of the principal concerns expressed in New York was one of political accountability. ${ }^{315}$ Choosing a location to dispose of radioactive waste can be vitally important but also politically quite unpopular. As such, there may be a strong incentive for federal officials to force such unpopular decisions onto state officials in order "to avoid being held accountable to the voters for the choice of location." 316 Likewise, state officials might be all too happy to avoid accountability by shifting blame on to the federal government.

The Court later deployed this anti-commandeering principle in striking down a portion of the Affordable Care Act in National Federation of Independent Business $v$. Sebelius. ${ }^{317}$ The Court held that, while Congress can grant conditional funding to states to encourage compliance with federal programs, it may not use its spending power to coerce states into compliance. $^{318}$ The Court held that the threat to withdraw all Medicaid funding if a state did not accept the expansion of the program was not a permissible inducement but "a gun to the head." 319 Such coercion, according to the majority, amounts to commandeering, which "would threaten the accountability key to our federal system." ${ }^{320}$ Thus, state consent-which is of core

${ }^{310}$ See John F. Manning, Clear Statement Rules and the Constitution, 110 CoLum. L. Rev. 399, 409 (2010) (noting that Gregory's clear statement rule was erected against the "backdrop" of National League of Cities' "traditional governmental functions" test "that Garcia had found inappropriate for Marbury-style judicial review").

311501 U.S. 452, 470 (1992)

${ }^{312}$ Id. at 460 .

${ }^{313}$ See Siegel, supra note 293 , at 1636.

314505 U.S. 144, 188 (1992).

${ }^{315}$ See id. at 182.

${ }^{316} \mathrm{Id}$. at $182-83$.

317132 S. Ct. 2566, 2602 (2012); see also Andrew B. Coan, Commandeering, Coercion, and the Deep Structure of American Federalism, 95 B.U. L. Rev. 1, 3 (2015) (noting that the Court "drew an explicit line between Congress's conditional spending power and the anticommandeering principle").

${ }^{318}$ See Sebelius, $132 \mathrm{~S}$. Ct. at 2602.

${ }^{319} \mathrm{Id}$. at 2604.

${ }^{320} \mathrm{Id}$. at 2602. 
importance to municipal bankruptcy laws-may permit the federal government to influence and direct state policies. However, that consent must be truly voluntary and not coerced.

This section by no means exhausts the debates over federalism doctrine. Its aim is more targeted: to highlight ways in which-once freed from the formalist Great Divide Model-courts may think more fruitfully about the limits of federal intrusion into state power, both when a city has filed bankruptcy and when a state has sought to address municipal insolvency under state law.

\section{Re-Thinking the Limits of Federal Bankruptcy Courts' Power}

These broader federalism principles help to identify the federalism issues in the municipal bankruptcy context, in particular, those issues that arise from bankruptcy court control. Specifically, they create a framework for considering the indirect federal interference of the "Detroit Blueprint" 321 and for considering Gillette and Skeel's proposal for even greater federal intervention in Chapter 9.322

Using bankruptcy courts to restructure local government structureswhether indirectly or directly-raises political process concerns of the sort raised in Garcia. Examining municipal bankruptcy federalism under process-oriented federalism, the focus should be the legislative process rather than the substance of the bankruptcy laws. Thus, perhaps there is no need to worry about federal bankruptcy intrusion into local governance because the states exercise two layers of political control: (1) the states may opt out of the municipal bankruptcy laws, and (2) the states may impose limitations on federal power by amending the bankruptcy laws.

Leaving aside the issue of state consent for the moment and focusing on the second level of state control_-that the states may amend the federal bankruptcy laws - there may still be procedural problems. It is one thing for federal law directly to require specific changes to local government structures in Chapter 9, but a different thing for Congress to delegate that power to bankruptcy courts. As Johnson and Young point out, when considering the implications of a theoretical bankruptcy law as applied to the states, "Although Garcia allows Congress to regulate the states' governmental operations, it is not nearly so clear that Congress may turn over control of state financial decisions to federal judges." 323 If a linchpin of procedural safeguards is that the political process may sufficiently protect state interests, there may be serious concerns about assigning power to apolitical actors. As expressed in the Garcia dissent, procedural federalism may overstate the

321 See Jacoby, supra note 24.

${ }^{322}$ Gillette \& Skeel, supra note 6.

${ }^{32.3}$ Emily D. Johnson \& Ernest A. Young, The Constitutional Law of State Debt, 7 DukE J. Const. L. \& Pub. Pol'y 117, 158-59 (2011). 
connection between states and the myriad of unelected civil service employees that draft federal legislation. ${ }^{324}$

These delegation concerns are further complicated by the unique (and uncertain) status of bankruptcy judges. Unlike Article III judges that are appointed by the president and confirmed by the Senate, bankruptcy judges are appointed by the federal courts of appeal to serve fourteen-year terms. ${ }^{325}$ On the one hand, states have an even more attenuated connection with bankruptcy judges than they do with district judges, since they have only the most minimal control over the appointment of bankruptcy judges. On the other hand, bankruptcy judges do not enjoy the life tenure and salary protections Article III judges possess. ${ }^{326}$ Congress thus has greater power to remove bankruptcy judges, providing more control over the bankruptcy judiciary than over other federal judges. ${ }^{327}$

A second constitutional concern arises from the anti-commandeering cases. As recognized by Gillette and Skeel, this may be a serious obstacle to court involvement in operational restructuring, as the bankruptcy laws may be understood as forcing states to submit to federal control in exchange for obtaining the benefit of debt relief. ${ }^{328}$ The anti-commandeering principle has been applied not only to prohibit Congress from compelling state governments to participate in federal regulatory programs, but also to prohibit Congress from using its spending power to coerce states to enact federal regulatory programs. ${ }^{329}$ A principal justification for this concern is that of political accountability, as federal coercion may obfuscate the decision-making process and confuse the electorate. ${ }^{330}$

${ }^{324}$ See Garcia v. San Antonio Metro. Transit Auth., 469 U.S. 528, 566-67 (1985) (Powell, $\mathrm{J}$., dissenting).

${ }^{325} 28$ U.S.C. $\$ 152$ (2012). This non-Article III status may raise important questions of bankruptcy courts' constitutional authority to enter final judgments in their potential role in restructuring municipal governance. See Stern v. Marshall, 131 S. Ct. 2594, 2611 (2011) (holding that bankruptcy courts lack the constitutional authority to determine state law counterclaims). However, this article leaves such Stern matters to the side.

${ }^{326}$ See Johnson \& Young, supra note 323 , at 159 n.205.

${ }^{327}$ Congress's removal power is currently limited by statute, which permits removal only "when a vacancy exists by reason of resignation, retirement, removal, or death." 28 U.S.C. $\S 152$ (b)(3) (2012). Only judges in the judicial council where the bankruptcy court is located may remove a bankruptcy judge, and "only for incompetence, misconduct, neglect of duty, or physical or mental disability." 28 U.S.C. \$ 152(e) (2012).

${ }^{328}$ Gillette \& Skeel, supra note 6, at 1208; see also Johnson \& Young, supra note 323, at 140 (analyzing the constitutional problems of conditioning state bailouts on "demands that a state alter its constitution"). Of course, a bankruptcy is not a bailout, as Johnson and Young recognize. But the concerns they identify are analogous to that of conditioning debt relief on alternations to local governance.

${ }^{329}$ See Nat'l Fed'n of Indep. Bus. v. Sebelius, 132 S. Ct. 2566, 2602 (quoting New York v. United States, 505 U.S. 144, 178 (1992) (" "[T]he Constitution simply does not give Congress the authority to require the States to regulate. That is true whether Congress directly commands a State to regulate or indirectly coerces a State to adopt a federal regulatory system as its own." "); see also Coan, supra note 317, at 3 (summarizing Sebelius as holding that "coercive exercises of the conditional spending power and commandeering amount to the same thing").

${ }^{330}$ See Sebelius, 132 S. Ct. at 2578. 
Municipal bankruptcy laws do not offer federal funds; they offer a discharge of indebtedness that is unavailable under state law. In effect, as McConnell describes it, municipal bankruptcy law may be understood as "the Federal government lending to cities and states its power to impair contracts, a power otherwise reserved under the Constitution for the Federal government." 331 If that discharge is offered on the condition that states raise taxes, restructure their local governments, or take other mandated steps of operational reorganization, this is very much like conditional spending. ${ }^{332}$ The question, then, is whether that condition raises political accountability problems.

The current system of judicial control "by a wink and a nod" may present serious concerns on this front. When the federal government makes conditions, it must do so explicitly. ${ }^{333}$ It is not clear that the municipal bankruptcy laws now do that sufficiently well. In fact, facially, the statutory safeguards of Sections 903 and 904 appear to prevent federal intrusion into local governance at all. It is only through indirect and under the radar procedural devices that courts can intrude upon local governance. ${ }^{334}$ This indirect control seems particularly problematic from the standpoint of political accountability. In fact, as Levitin argues, the ability of courts to do just this may be deliberately designed to obfuscate the decision-making process for politically unpopular decisions, such as how to treat public pension plans. ${ }^{335}$ In this sense, public pension reform is similar to finding a site for nuclear waste disposal: it's something that needs to be done, but preferably by someone else.

Even if Congress amended the municipal bankruptcy laws to be more explicit as to these conditions, it is not clear that this would solve the problem. As Gillette and Skeel acknowledge, "[T] he right of a state to determine the governance structure of its cities could be seen, in a sense, as inalienable." ${ }^{336}$ The Court has reiterated this concern-expressed in Ashton through New York-that the states may not expand the powers given to Congress. ${ }^{337}$ And even when conditions are stated unambiguously, there may be serious concerns of political accountability, as states would be delegating unpopular decisions to a federal court.

${ }^{331}$ Michael W. McConnell, Extending Bankruptcy Law to States, in WhEN STATES Go Broke 233 (Peter Conti-Brown \& David A. Skeel, Jr., eds., 2012) (describing this as a way of understanding the theory behind Bekins, a theory he ultimately rejects because bankruptcy law gives significant, indirect control to bankruptcy courts over local governance).

${ }_{332}$ Gillette \& Skeel, supra note 6, at 1209.

${ }^{333}$ See Arlington Cent. Sch. Dist. Bd. of Educ. v. Murphy, 548 U.S. 291, 296 (2006) ("Congress has broad power to set the terms on which it disburses federal money to the States, but when Congress attaches conditions to a State's acceptance of federal funds, the conditions must be set out unambiguously.") (internal citations and quotations omitted).

${ }^{334}$ See Jacoby, supra note 24; McConnell \& Picker, supra note 23.

${ }^{335}$ Levitin, supra note 2.

${ }^{336}$ Gillette \& Skeel, supra note 6, at 1215.

${ }^{337}$ See generally Ashton v. Cameron Cty. Water Improvement Dist., 298 U.S. 513 (1936); New York v. United States, 505 U.S. 144 (1992). 
Gillette and Skeel ultimately argue that the consensual nature of municipal bankruptcy should assuage these anti-commandeering concerns because states have the right to opt out of the municipal bankruptcy laws, the conditional discharge would be more voluntary than was the conditional Medicaid funding in NFIB. ${ }^{338}$ While this seems correct, the central role they assign to consent will always appear problematic in the absence of a decisive break with the Great Divide Model and the move to a more functionalist model, which better accommodates analysis of what constitutes consent. Nothing better illustrates the need for this break than the Court's approach in the Puerto Rico litigation.

\section{State Consent and the Puerto Rico Litigation}

The Puerto Rico litigation is, in some respects, a strange place to look for analyzing the role of state consent. Puerto Rico is not a state but a commonwealth, whose relationship with the United States is entirely unique. ${ }^{339}$ This litigation, though, serves to illustrate how the Great Divide Model may aggrandize federal control over municipal financial restructuring in a way that, if applied to the states (as the Court suggests), might undermine the validity of state consent. The question in Puerto Rico v. Franklin, as discussed supra, was whether Puerto Rico's Recovery Act-which would provide a bankruptcy-like procedure for Puerto Rican public corporations-was preempted by the Bankruptcy Code. Puerto Rican municipalities and public corporations are excluded from relief under Chapter 9 of the Bankruptcy Code, leaving open the question whether Puerto Rico could fill this gap or whether Puerto Rico was stuck without a solution to its public debt crisis.

Justice Thomas, writing for the majority, held that Section 903(1) preempts the Recovery Act. ${ }^{340} \mathrm{He}$ reasoned that the language of Section 903(1) applies to all "states," and the Bankruptcy Code defines "state" to include Puerto Rico (except for determining whether Puerto Rico was eligible to be a debtor). As such, he broadly stated that Section 903(1) would preempt all "state municipal bankruptcy laws," regardless of whether a state had opted into the municipal bankruptcy option. That is, even those twentysix states that have not opted into Chapter 9 (as well as Puerto Rico and Washington, D.C., which are statutorily excluded from Chapter 9 relief) could no longer enforce their own municipal bankruptcy laws. ${ }^{341}$

This broad preemption is consistent with the legislative history of Section 903(1). However, it raises important questions of the importance of state consent. In Faitoute, the Court considered a similar issue as applied to a New Jersey statute and concluded that Congress did not intend to preempt

${ }^{338}$ Gillette \& Skeel, supra note 6, at 1215.

${ }^{339}$ See Puerto Rico v. Sanchez Valle, 136 S. Ct. 1863, 1868 (2016) (describing the "unique political relationship" between the United States and Puerto Rico).

${ }^{340}$ See Puerto Rico v. Franklin Cal. Tax-Free Tr., 136 S. Ct. 1938, 1944 (2016).

${ }^{341}$ See Pew Charitable Trusts, supra note 7. 
state financial rescue laws. ${ }^{342}$ That opinion could be read as assuming that this decision reflected a simple policy choice to not preempt state laws. In that case, the subsequent amendment preempting state composition laws would be a valid exercise of congressional authority. That opinion, though, suggests this was not a policy choice to leave state laws intact but rather a belief that preemption would upset the delicate constitutional balance Congress had struck in crafting the municipal bankruptcy laws. Taking away the state option, that is, might upset the balance of federal and state power.

The Court, though, did not consider this question at all in the Puerto Rico litigation. It simply concluded that Section 903(1) could preempt all state composition laws, regardless of whether a state had opted into the municipal bankruptcy laws. By not considering this issue at all, the case could read as suggesting that municipal bankruptcy law does not need an "opt in" feature. If Congress can displace state control over municipal insolvency even without state consent, perhaps state consent is not so important after all.

Such a broad reading is consistent with the Great Divide Model, as it would place municipal bankruptcy laws within the federal sphere of power, thus vitiating the need for state consent of any kind. Such a reading, though, is inconsistent with the history and development of the municipal bankruptcy laws, which have consistently treated state consent as an essential feature of municipal bankruptcy law. It also would place a great deal of weight on a case in which those consent issues were arguably absent, given that Puerto Rico's status as a territory would not have raised state sovereignty concerns. ${ }^{343}$

When municipal bankruptcy law is understood as a more cooperative regime, one that intends to preserve the states' control over local governance while respecting the federal power to pass uniform bankruptcy laws, the importance of state consent is obvious: there can be no cooperation without state consent. A broad reading of Justice Thomas's decision, therefore, would drastically and problematically alter federal-state relations in this field. As to states that have not authorized a municipal bankruptcy filing, this interpretation of Section 903 would effectively expand the Contracts Clause. Cities like Pontiac that are trying to address financial distress would face federal restraints not only under the Contracts Clause but also under the bankruptcy laws. States would thus lose the ability to regulate under any law that would fit under the banner of a "municipal bankruptcy law." Such a result would lump together operational and financial restructuring laws in a way that is inconsistent with the statutory structure of Chapter 9 and upend its underlying constitutional foundation.

This narrower reading is consistent not only with the structure of Sections 903 and 904, but it also comports with the notion of state consent more

${ }^{342}$ See Faitoute Iron \& Steel Co. v. City of Asbury Park, 316 U.S. 502, 507 (1942).

${ }^{343}$ See Franklin Cal. Tax-Free Tr. v. Puerto Rico, 805 F.3d 322, 344-45 (1st Cir. 2015) (identifying, but avoiding, this issue on the grounds that Puerto Rico's territorial status does not implicate the Tenth Amendment), aff'd, 136 S. Ct. 1938 (2016). 
broadly. As Justice Frankfurter recognized in Faitoute, "[T]he bankruptcy power is exercised ... only in a case where the action of the taxing agency in carrying out a plan of composition approved by the bankruptcy court is authorized by state law." ${ }^{344}$ Thus, bankruptcy law does not come into play unless and until the state has authorized the municipality to seek bankruptcy relief. This result was not policy driven; rather, it was "carefully drawn so as not to impinge on the sovereignty of the State." 345

This approach also avoids the larger constitutional anti-commandeering concerns that would arise if state consent were eroded. If Congress could strip states of their ability to address municipal insolvency, then the states' "consent" to the federal bankruptcy laws looks much more like coercion. It would also undermine the political safeguards against federal intrusion, as it would effectively force states to use bankruptcy to address municipal insolvency. By limiting states from addressing municipal insolvency on their own, Congress is effectively forcing states to "consent" to the bankruptcy option. ${ }^{346}$ That is, by taking away a state's ability to address municipal insolvency on its own, Congress is pushing states towards the federal bankruptcy option, thus undermining state consent.

\section{Conclusion}

This article has argued that municipal bankruptcy federalism has unhappily been stuck in the language and framework of an outdated model of federalism. When faced with questions of federal interaction with state law, that model presumes independent regulatory spheres of federal and state power-debt regulation belongs to the federal, operational regulation to the states. It has then identified three problems with this Great Divide Model. First, its formalist nature obscures the decision-making process, particularly as applied to matters where debt and governance overlap. Second, it fails to provide useful guidance to courts on how to balance the state and federal interests in municipal insolvency. And third, the Great Divide Model creates a distance between municipal bankruptcy federalism and general principles of federalism-resulting in a schema that is incapable of identifying and analyzing the more complex relationship between federal and state governments in the context of municipal insolvency.

Accordingly, this article has argued for a shift towards a more functionalist approach to municipal bankruptcy federalism-an approach that takes into account the purposes and goals of municipal bankruptcy, recognizing the interest of the state. Such a functional approach creates an analytical framework for defining the role of states to reorganize their distressed municipalities. Furthermore, and perhaps even more importantly, it creates tools

\footnotetext{
344316 U.S. at 1132.

345 Id.

${ }^{346} C f$. Nat'l Fed'n of Indep. Bus. v. Sebelius, 132 S. Ct. 2566 (2012).
} 
for imposing limits on the reach of federal bankruptcy courts into the operational arena of distressed municipalities. 